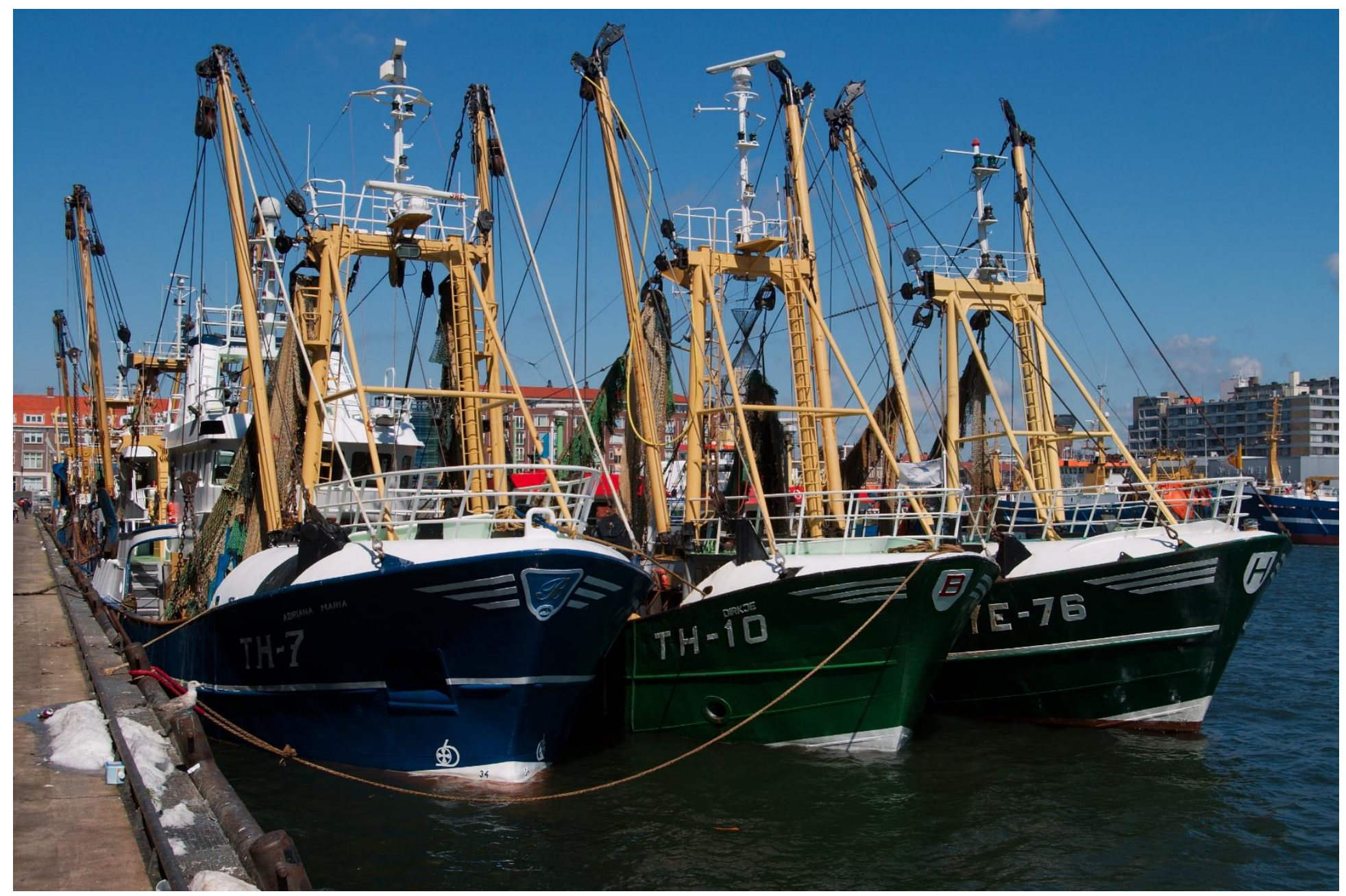

\title{
Exploring potential ecological impacts of different scenarios for spatial closures and fleet decommissioning for Dutch North Sea demersal fisheries
}

Authors: Niels Hintzen ${ }^{1}$, Esther Beukhof ${ }^{1}$, Thomas Brunel ${ }^{1}$, Annemiek Eweg ${ }^{2}$, Katell Hamon ${ }^{2}$, Susan de Koning ${ }^{1}$, Arie $\mathrm{Mol}^{2}$, Nathalie Steins ${ }^{1}$

${ }^{1}$ Wageningen Marine Research

${ }^{2}$ Wageningen Economic Research 


\section{Exploring potential ecological impacts of different scenarios for spatial closures and fleet decommissioning for Dutch North Sea demersal fisheries}

Author(s): Niels Hintzen ${ }^{1}$, Esther Beukhof ${ }^{1}$, Thomas Brunel $^{1}$, Annemiek Eweg ${ }^{2}$, Katell Hamon ${ }^{2}$, Susan de Koning ${ }^{1}$, Arie $\mathrm{Mol}^{2}$, Nathalie Steins ${ }^{1}$

${ }^{1}$ Wageningen Marine Research

${ }^{2}$ Wageningen Economic Research

This research project was carried out by Wageningen Marine Research and subsidized by the ministry of Agriculture, Nature and Food Quality for the purposes of Policy Support Research Theme 'Nature-inclusive Fisheries' (project no. BO-43-023.02-004).

Wageningen Marine Research

IJmuiden, March 2021

CONFIDENTIAL no

Wageningen Marine Research report C029/21 
Keywords: offshore wind energy, demersal fisheries, ecological impact, decommissioning, displacement, marine protected areas, emission, benthos, unwanted bycatch, $\mathrm{CO}_{2}$-footprint.

Client: $\quad$ Ministry of Agriculture, Nature and Food Quality

Attn.: J.T.H. Hoogbergen

PO Box 20401

2500 EK Den Haag, The Netherlands

BO-43-023.02-004

This report can be downloaded for free from https://doi.org/10.18174/544217

Wageningen Marine Research provides no printed copies of reports

Wageningen Marine Research is ISO 9001:2015 certified.

Photo cover: Nathalie Steins

(C) Wageningen Marine Research

Wageningen Marine Research, an institute Wageningen Marine Research accepts no liability for consequential damage, nor within the legal entity Stichting for damage resulting from applications of the results of work or other data Wageningen Research ( $a$ foundation under obtained from Wageningen Marine Research. Client indemnifies Wageningen Dutch private law) represented by Dr. ir. Marine Research from claims of third parties in connection with this application. J.T. Dijkman, Managing Director All rights reserved. No part of this publication may be reproduced and / or

KvK nr. 09098104, published, photocopied or used in any other way without the written permission WMR BTW nr. NL 8113.83.696.B16.

Code BIC/SWIFT address: RABONL2U

IBAN code: NL 73 RABO 0373599285 


\section{Contents}

\section{Samenvatting}

$1 \quad$ Introduction

11

$1.1 \quad$ Dutch North Sea in transition $\quad 11$

1.2 Research question $\quad 12$

1.3 Scenarios $\quad 12$

1.4 Study approach $\quad 15$

1.5 Report structure $\quad 16$

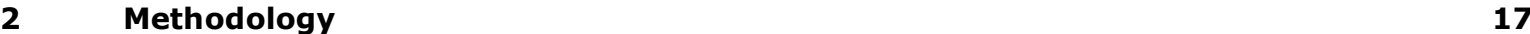

$\begin{array}{llr}2.1 & \text { Data sources } & 17\end{array}$

$\begin{array}{lll}2.2 & \text { Scenario development } & 17\end{array}$

2.3 Defining assumptions underlying the effort displacement under different scenarios 18

$\begin{array}{ll}\text { 2.3.1 Historic footprint \& total catch } & 18\end{array}$

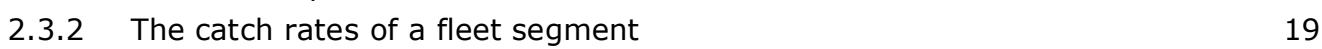

2.3.3 The visiting frequency and maximum time spend at fishing grounds 20

$\begin{array}{ll}2.3 .4 & \text { Displacement of fishing effort }\end{array}$

$\begin{array}{lll}2.4 & \text { Selection of vessels to decommission } & 21\end{array}$

2.4.1 Probability of opting for the decommissioning scheme $\quad 21$

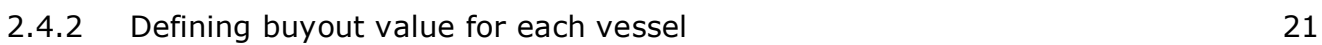

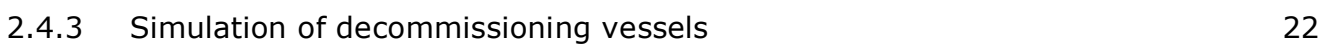

2.5 Calculation of three indicators representing ecosystem impact 23

2.5.1 Change in benthic biomass in the Dutch EEZ 23

2.5.2 $\mathrm{CO}_{2}$ emissions by the Dutch fishing fleet $\quad 24$

$\begin{array}{ll}2.5 .3 & \text { Change in unwanted bycatch }\end{array}$

$\begin{array}{llr}3 & \text { Results } & 27\end{array}$

$\begin{array}{lll}3.1 & \text { Simulation of drivers for decommissioning } & 27\end{array}$

$\begin{array}{ll}3.2 & \text { Effort displacement }\end{array}$

$\begin{array}{lll}3.3 & \text { Impact on benthos } & 32\end{array}$

3.4 Impact on $\mathrm{CO}_{2}$ emissions $\quad 32$

3.5 Impact on unwanted bycatch $\quad 33$

$\begin{array}{lll}3.6 & \text { Qualitative summary of the results } & 34\end{array}$

4 Discussion $\quad 35$

$\begin{array}{lll}4.1 & \text { Main results } & 35\end{array}$

$\begin{array}{lll}4.2 & \text { Critical assumptions } & 36\end{array}$

$\begin{array}{lll}4.3 & \text { Implications of the results } & 37\end{array}$

$\begin{array}{lll}4.4 & \text { Uncertainty of the simulations } & 38\end{array}$ 
Annex A: Selection criteria for vessels eligible for decommissioning 


\section{Summary}

The Dutch government aims to expand renewable energy production and areas for nature conservation in the North Sea. These developments are part of its commitment to the Paris Agreement, implemented in Dutch legislation through the Climate Law ('Klimaatwet', 2019), and the Dutch North Sea Agreement (NZA) involving the main economic users affected by offshore wind farm development and nature conservation organisations (OFL, 2020). As sea space is limited, developing offshore wind farms and establishing (additional) marine protected areas will cause displacement of the Dutch fishing fleet. Displacement will possibly result in higher fishing pressure in those areas that remain accessible for fishers. In this study, we assess the potential ecological impact of different spatial closure scenarios. Our study area is the North Sea (ICES division 4.a-c) and the eastern English Channel (ICES division 7.d) between 49 and $60^{\circ} \mathrm{N}$ latitude. We compare situations in which part of the fleet is decommissioned (with the catch of the decommissioned vessels either exploited or not exploited by the remaining fleet) and situations in which no decommissioning takes place. All scenarios are compared to a Status Quo scenario, i.e., the current situation with regard to closed areas, catch level and fleet size.

We use seven scenarios:

1. SQ: Status Quo.

2. Wind: Expansion of Offshore Wind Farms (2030), no additional Marine Protected Areas.

3. NZA (North Sea Agreement): Expansion of Offshore Wind Farms and Marine Protected Areas.

4. Decom NZA vessels: Expansion of Offshore Wind Farms and Marine Protected Areas combined with a decommissioning scheme of vessels only (all catch of decommissioned vessels being fished by the remaining fleet).

5. Decom NZA vessels + catch: Expansion of Offshore Wind Farms and Marine Protected Areas combined with a decommissioning scheme of vessels including their catch (representing the far end of the spectrum where, for different reasons, none of the catch of the decommissioned vessels can be fished by the remaining fleet).

6. Hard Brexit: Expansion of Offshore Wind Farms and Marine Protected Areas and the closure of all British Waters to Dutch fishers as part of Brexit.

7. Decom Hard Brexit vessels: Expansion of Offshore Wind Farms and Marine Protected Areas and the closure of all British Waters to Dutch fishers combined with a decommissioning scheme of vessels only (all catch of decommissioned vessels being fished by the remaining fleet).

At the time when the study was commissioned by the Dutch Ministry of Agriculture, Nature and Food Quality, there was no indication of the eventual outcome of the Brexit negotiations. It was agreed to assume the worst-case scenario (Hard Brexit). We stress that the Hard Brexit scenario used in this study does not reflect the final outcome of the actual Brexit agreement of 24 December 2020 (EU et al., 2020), when this study was already near completion.

Because the effect of the decommissioning scheme is influenced by the selection of decommissioned vessels, we simulate the possible ecological outcomes based on the probability that a vessel opts for decommissioning in the scenarios including a decommissioning scheme (scenarios 4, 5 and 7). We determine this probability for the vessels of the 2019 fleet based on individual factors chosen from literature and expert judgement. Given the uncertainty on which vessels may opt for decommissioning, we did this simulation 100 times, resulting in 100 different groups of vessels that are decommissioned in the simulation. In the simulations, this results into a bandwidth of ecological impact results.

To determine the impact of the different scenarios on the ecology of the North Sea, we chose three ecological indicators :

1. Impact on benthos.

2. Impact on $\mathrm{CO}_{2}$-emissions. 
For each scenario, we determine the change in the three indicators in comparison to the Status Quo scenario.

In summary, the results of this study are as follows:

- $\quad$ The construction of windfarms (Wind, scenario 2) and allocation of Natura 2000 areas (NZA, scenario 3; Decommissioning NZA vessels, scenario 4) has limited impact on the three ecological indicators.

- In all scenarios (2-6), the positive impact of area closures on benthos is evened out by increases in fishing pressure in the remaining open areas..

- The impact on unwanted bycatch strongly depends on the spatial location of the additional closures and the distribution of bycatch species. Only for rays, all scenarios, except for 2 (Wind), show a positive effect on unwanted by-catch. From a life history perspective, rays are the most vulnerable species in our assessment.

- $\quad$ The ecological impact of a Hard Brexit (scenario 6) will generally result in higher $\mathrm{CO}_{2}$ emissions (as more effort is needed to catch the same volume of fish) and results in lower bycatch, but will have a negative effect on benthic species.

- Decommissioning part of the Dutch demersal fleet is expected to have a positive effect on the ecology when compared to the situation where areas are closed without a fleet decommissioning scheme and the same number of vessels continues fishing on a much smaller area. As a result of decommissioning, total catches will decline and hence also the effort needed to realise these catches (i.e. scenario 3 vs scenario 4 ).

- In a scenario when the catch of the decommissioned vessels is no longer fished by the remaining fleet (scenario 5), a substantial positive ecological effect can be expected compared to the scenario in which there is only decommissioning (4).

A qualitative overview of the direction of the changes in ecological impacts for the different scenarios in comparison to the Status Quo scenario (1), is shown in Table S1.

\section{Table S1}

Qualitative summary of the results on the ecological indicators for scenarios without decommissioning (2, 3 6) and with decommissioning (4, 5, 7), compared to Status Quo. Upward pointing arrows indicate an increase, horizontal pointing arrows indicate no change and downward pointing arrows indicate a decrease.

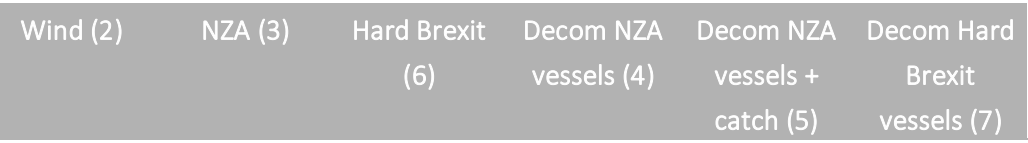

Impact on benthos

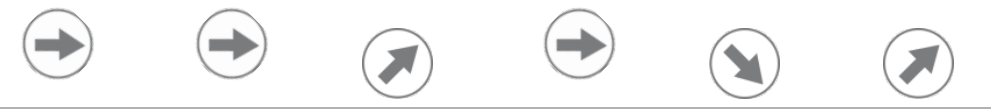

$\mathrm{CO}_{2}$ emissions
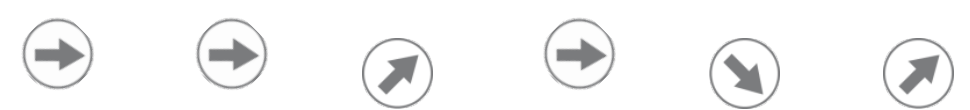

Bycatch
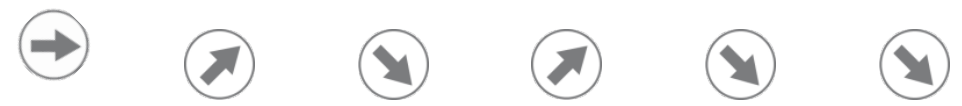

The results are driven primarily by three critical assumptions:

1. Within a grid cell, Catch per Unit of Effort (CPUE) at the start of a month is defined based on historical data and is not affected within a simulation due to displacement and effort changes. CPUE decreases with fishing effort following Rijnsdorp et al. (2011), and CPUE is reset to its initial value at the beginning of each month.

2. There is no cap on effort in any grid cell.

3. Fishing effort is displaced only to areas previously visited by the fleet segments. 
Under decommissioning scenarios it is likely that the remaining fleet will not only fish in the areas they previously fished, but will also displace effort to fishing grounds previously visited by decommissioned vessels. Under this assumption, results will become intermediate between NZA (3) and Decommissioning NZA vessels (4) or Hard Brexit (6) and Decommissioning Hard Brexit scenario (7) results.

The results for the different scenarios as presented in this report should be seen relative to each other. This modelling study is an explorative exercise into the direction of ecological responses to reallocation of fishing effort of the Dutch demersal fleet under different closure scenarios. The projected directions of development are indicative of the expected ecological response rather than quantitative precise estimates. We note that there are currently no agreed reference points defined for any of the ecological indicators, for example as part of the European Marine Strategy Framework Directive. As such, aiming for improvement of these ecological indicators is not based on the assumption that they are currently in a bad/poor state.

Our analyses were limited to the data of the demersal fleet under Dutch registration (in and outside the Dutch Economic Exclusive Zone of the North Sea). This results in more conservative outcomes, as impacts are considered only relative to the entire Dutch fishery and not to a larger international fishery.

Whether or not after decommissioning, the remaining fishers will be able to catch the same value of fish as is caught by the current fleet, is unclear. To exploit additional quota, the remaining fishers will need to spend, per individual, additional time at sea. This may lead to local depletion of fish stocks if they choose to fish in their known hotspots and even, because of cost-benefits considerations, lead to quota not being fully exploited in the end. Our current model cannot account for local depletion scenarios.

We stress that the prediction of the distribution of all fleet segments is complex, as in practice fishing behaviour is related to many factors including abundance and distribution of target species, quota allocations (and possibilities for international quota swaps or quota leases amongst Dutch fishers), historic preferences for fishing locations (personal knowledge about fishing grounds) combined with other choices fishers make at sea.

It is also important to take into account that in this study, fishers still fish in areas associated with high steaming costs or that are surrounded by closed areas. Cost-effective adaptation in behaviour (including limitations in effort and economic constraints of individual vessels) is not considered. Specialized individual-based fleet behavioural models are required to evaluate whether these areas would still be fished. Such a model is currently not available, but could result in different predicted outcomes in terms of displacement and ecological impacts. In view of the many marine spatial planning changes that will occur in the North Sea over the next years, the development of a full dynamic fleet behavioural model is needed. 


\section{Samenvatting}

De Nederlandse overheid wil de productie van hernieuwbare energie en gebieden voor natuurbescherming op de Noordzee uitbreiden. Deze ontwikkelingen zijn onderdeel van het Akkoord van Parijs, die in Nederland in de Klimaatwet (2019) zijn vastgelegd, en van het Noordzee Akkoord met de belangrijkste economische gebruikers rond windenergie op de Noordzee en de natuurorganisaties (OFL, 2020). De ruimtelijke beperkingen die samen gaan met windparken op zee en (extra) natuurbeschermingsgebieden leiden tot verplaatsing van de visserijactiviteiten van de Nederlandse vloot. Dit leidt mogelijk tot een hogere visserijdruk in de gebieden die voor vissers toegankelijk blijven. In deze studie bestuderen we de mogelijke ecologische effecten van verschillende scenario's. Ons studiegebied is de Noordzee (ICES divisie 4.a-c) en het oostelijk deel van Het Kanaal (ICES divisie 7.d) tussen 49 en $60^{\circ}$ Noorderbreedte. We vergelijken situaties waarin een deel van de vloot wordt gesaneerd (waarbij de vangsten die aan de Status Quo situatie gerelateerd zijn, al dan niet voor de resterende vloot beschikbaar blijven) met situaties waarin geen sanering plaatsvindt. We vergelijken alle scenario's met het Status Quo scenario, ofwel de huidige situatie met betrekking tot gesloten gebieden, vangsten en vlootomvang. We gebruiken zeven scenario's:

1. Status quo.

2. Wind: Uitbreiding van offshore windparken (2030).

3. NZA: Uitbreiding van offshore windparken en beschermde gebieden.

4. Decom NZA schepen: Uitbreiding van offshore windparken en beschermde gebieden gecombineerd met een saneringsregeling (alle vangsten van de gesaneerde schepen blijven in de operationele vloot).

5. Decom NZA schepen+historische vangst: Uitbreiding van offshore windparken en beschermde mariene gebieden in combinatie met vlootsanering waarbij de vangsten van gesaneerde schepen niet meer beschikbaar zijn voor de resterende vloot (dit scenario vertegenwoordigt het uiterste einde van het spectrum waarbij, om verschillende redenen, de vangsten van de gesaneerde schepen niet volledig kunnen worden benut door de blijvers).

6. Hard Brexit: Uitbreiding van offshore windparken en beschermde gebieden en de sluiting van alle Britse wateren voor Nederlandse vissers (Harde Brexit).

7. Decom Hard Brexit: Uitbreiding van offshore windparken en beschermde gebieden en de sluiting van alle Britse wateren voor Nederlandse vissers (Harde Brexit) in combinatie met vlootsanering (met behoud van vangsten van gesaneerde schepen in de operationele vloot).

Toen het ministerie van Landbouw, Natuur en Voedselkwaliteit opdracht gaf voor deze studie, was er nog geen enkele duidelijkheid over de mogelijke uitkomsten van Brexit voor de visserij. Daarom is besloten het 'worst case scenario' aan te houden. Het Harde Brexit scenario in deze studie komt dus niet overeen met de uitkomsten van het daadwerkelijke Brexit akkoord van 24 december 2020 (EU et al., 2020), dat vlak voor afronding van deze studie werd bereikt.

Voor de scenario's waarin een saneringsregeling is opgenomen, simuleren we de mogelijke ecologische uitkomsten op basis van de kans dat een schip kiest voor sanering. We hebben deze kans bepaald op basis van literatuur en deskundigenoordeel. De simulatie is 100 keer gedaan. Dit resulteert in 100 groepen schepen met verschillende samenstellingen. In de simulatie resulteert dit in een bandbreedte aan resultaten met betrekking tot de ecologische impact.

Het effect van de saneringsregeling wordt beïnvloed door de selectie van de buiten bedrijf gestelde vaartuigen. Daarom worden de mogelijke ecologische resultaten gesimuleerd op basis van de kans dat een vaartuig kiest voor sanering (scenario's 4, 5 en 7). We hebben deze kans voor de vaartuigen van de vloot van 2019 bepaald op basis van individuele factoren die uit de literatuur en het oordeel van deskundigen zijn gekozen. We hebben deze simulatie 100 keer uitgevoerd. Op de manier houden we rekening te houden met onzekerheden over de keuze om al dan niet te saneren. Dit resulteert in 100 verschillende groepen vaartuigen die in de simulatie uit de vaart worden genomen. In de simulaties resulteert dit in een bandbreedte rond de resultaten van de ecologische impact. 
Om de impact van de verschillende scenario's op de ecologie van de Noordzee te bepalen, hebben we drie ecologische indicatoren gekozen:

1. Impact op het bodemleven.

2. Impact op $\mathrm{CO}_{2}$-uitstoot.

3. Impact op ongewenste bijvangst.

Voor elk scenario bepalen we de verandering in de drie indicatoren ten opzichte van het Status Quoscenario.

Samengevat zijn de belangrijkste resultaten:

- $\quad$ De verdergaande aanleg van windparken (Wind, scenario 2) en toewijzing van Natura 2000gebieden (NZA, scenario 3; Decom NZA vessels, scenario 4) hebben een beperkte impact op de drie ecologische indicatoren.

- In alle scenario's (2-6) wordt de positieve impact die gebiedssluitingen hebben op het bodemleven opgeheven door de toename van de visserijdruk in de gebieden waar wel nog gevist mag worden.

- De impact op ongewenste bijvangst van de verschillende scenario's (2-6) hangt sterk af van de locatie van de gebieden die additioneel worden gesloten en de verspreiding van de soorten in de ongewenste bijvangst. Alleen voor roggen hebben alle scenario's, met uitzondering van scenario 2 (Wind) een positief effect op ongewenste bijvangst. Roggen zijn de meest kwetsbare soort in onze beoordeling.

- $\quad$ De ecologische effecten van een Harde Brexit (scenario 6) zullen over het algemeen resulteren in een hogere $\mathrm{CO}_{2}$-uitstoot en minder bijvangst, maar hebben een negatief effect op bodemleven.

- $\quad$ Het saneren van een deel van de Nederlandse vloot heeft naar verwachting een positief effect op de ecologie vergeleken met de situatie warin gebieden worden gesloten zonder een saneringsregeling, waarbij hetzelfde aantal schepen blijft vissen op een veel kleiner gebied. Dit komt omdat de totale vangst naar beneden zal gaan en zodoende de benodigde inspanning om deze vangst te realiseren ook zal dalen.

- In een scenario waarin de vangsten van de gesaneerde vloot niet langer beschikbaar zouden zijn voor de resterende vloot (5), kan een substantieel positief ecologisch effect worden verwacht in vergelijking met het scenario waarin er alleen wordt gesaneerd (4).

Een kwalitatief overzicht van de richting van de veranderingen in ecologische effecten voor de verschillende scenario's in vergelijking met het Status Quo-scenario (i), staat in Tabel S1.

\section{Tabel S1}

Kwalitatieve samenvatting van de resultaten op de ecologische indicatoren voor verschillende scenario's zonder sanering $(2,36)$ en met sanering $(4,5,7)$, in vergelijking met de Status Quo. Pijlen die naar boven wijzen geven een stijging aan, horizontale pijlen zijn indicatief voor geen verandering, en neerwaartse pijlen betekenen een daling.
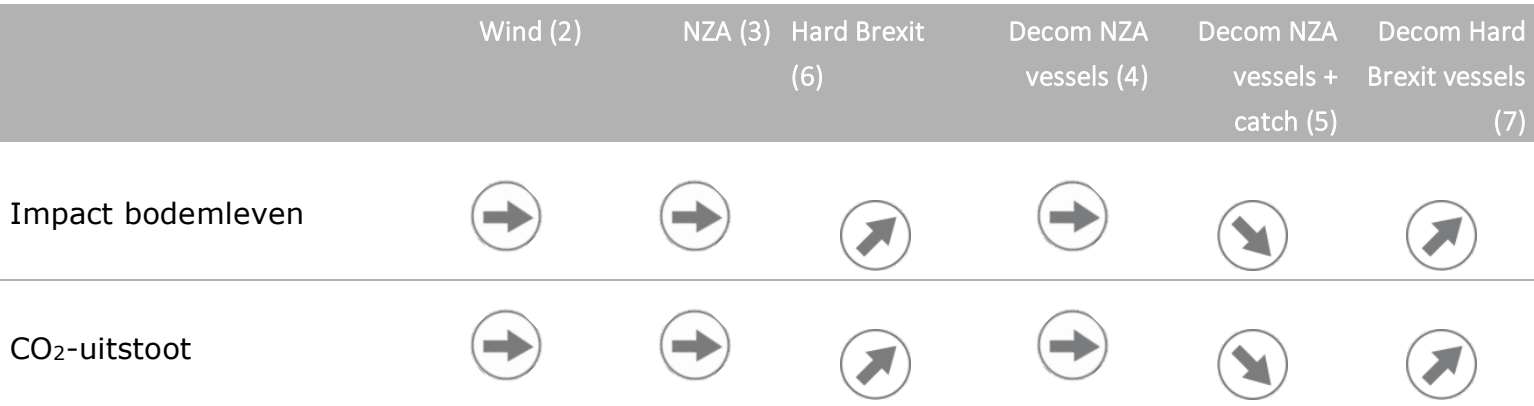

Ongewenste bijvangst
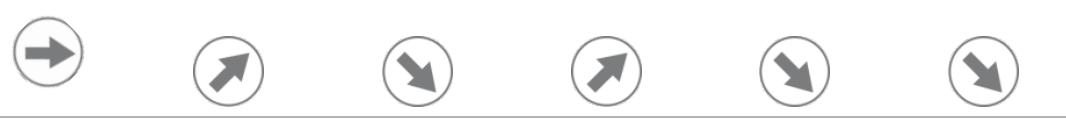
De resultaten worden vooral gedreven door drie kritische aannames:

1. In elke gridcel wordt de vangst per eenheid inspanning (CPUE) aan het begin van de maand gebaseerd op historische gegevens; deze start CPUE wordt binnen een simulatie niet beïnvloed als gevolg van veranderingen in visgebied en inspanning. De CPUE neemt af met de visserijinspanning op basis van Rijnsdorp et al. (2011), en de CPUE wordt aan het begin van elke maand gereset naar de startwaarde.

2. Er is geen begrenzing op de visserijinspanning in de gridcel.

3. De visserijinspanning wordt alleen verplaatst naar gebieden die eerder door de vlootsegmenten zijn bezocht.

In geval van sanering zal de resterende vloot waarschijnlijk een deel van de inspanning verplaatsen naar de visgronden die eerder door gesaneerde schepen werden bevist. Onder deze aanname zullen de resultaten tussen de resultaten voor de scenario's NZA (3) en NZA met sanering schepen (4) of Hard Brexit () en Hard Brexit met sanering (7) komen te liggen.

De uitkomsten van de scenario's moeten relatief ten opzichte van elkaar bekeken worden. Deze modelstudie is een verkenning van de richting van ecologische reacties op herverdeling van de visserij-inspanning van de Nederlandse demersale vloot onder verschillende sluitingsscenario's. Deze richtingen moeten vooral als indicatief voor de verwachte ecologische veranderingen worden gezien. Het zijn geen precieze kwantitatieve schattingen. We merken op dat er in het huidige beleid geen referentiepunten zijn gedefinieerd voor de gebruikte ecologische indicatoren, bijvoorbeeld vanuit de Europese Kaderrichtlijn Marien. Daarom is het streven naar verbetering van deze ecologische indicatoren niet gebaseerd op de interpretatie dat ze in de huidige situatie in een slechte staat zouden verkeren.

Voor het doen van de analyses waren we beperkt tot de gegevens van de demersale vloot die onder Nederlandse vlag vaart. Gegevens van vissersvloten uit andere landen (inclusief vlagkotters in handen van Nederlandse bedrijven) zijn niet meegenomen. De uitkomsten zijn daarom conservatief; impacts moeten worden beschouwd in relatie tot de Nederlandse vloot en niet in relatie tot de grotere inspanning van de internationale visserij.

Het is niet duidelijk of na een sanering van deel van de vloot, de overblijvende vissers dezelfde waarde aan vis kunnen vangen als die eerst door de saneerders werd gevangen. Om de vrijkomende quota te realiseren, zal de overblijvende vloot individueel meer tijd op zee moeten doorbrengen. Dit zou kunnen leiden tot lokale uitputting van visbestanden wanneer individuele vissers ervoor kiezen in hun eigen 'hot spots' te blijven vissen, en zelfs, vanwege kosten-baten afwegingen, tot het niet volledig benutten van quota. Ons model kan geen rekening houden met lokale uitputting scenario's.

We benadrukken dat het voorspellen van de verspreiding van de verschillende vlootsegmenten complex is. In de praktijk is visserijgedrag afhankelijk van vele factoren zoals de aanwezigheid van doelsoorten, beschikbare quota (en mogelijkheden van quotaruilen met andere landen en huur en verhuur tussen vissers onderling), historische voorkeuren voor visgronden (persoonlijke kennis van gebieden) in combinatie met andere keuzes die vissers op zee maken.

Een belangrijk punt is dat in deze studie vissers nog steeds vissen in gebieden waarvoor zij hoge stoomkosten moeten maken of die worden omgeven door gesloten gebieden. Aanpassingen in gedrag van individuele schepen om meer kosten efficiënt te vissen (inclusief beperkingen in inspanning en economische beperkingen) zijn buiten beschouwing gelaten. Om te kunnen evalueren of deze gebieden nog bevist zouden worden is een gespecialiseerd individueel vlootgedragsmodel nodig. Een dergelijk model is momenteel niet beschikbaar, maar zou kunnen leiden tot verschillende resultaten met betrekking tot verplaatsing van visserijinspanning en ecologische effecten. Met het oog op de vele aankomende veranderingen in het ruimtelijke gebruik van de Noordzee en de gevolgen daarvoor voor de verspreiding van de visserijactiviteiten, is de ontwikkeling dynamisch visserijgedragsmodel gewenst. 


\section{Introduction}

\subsection{Dutch North Sea in transition}

The Dutch part of the North Sea, also called the Dutch Exclusive Economic Zone (EEZ) is intensively used for several (economic) activities, such as shipping, oil- and gas production, fisheries and the production of renewable energy through the development of offshore wind farms (OWFs). Next to areas in which commercial activities take place, several areas in the Dutch EEZ are designated as marine protected areas (MPAs) under the European Union's Birds and Habitats Directives (N2000). To reach the goals of the Paris Agreement, implemented in Dutch legislation through the Climate Law ('Klimaatwet', 2019), renewable energy production should be increased. One of the government's strategies for increasing energy production is to develop new OWFs in the Dutch EEZ. By 2030, current OWFs will be scaled up from 957MW (2017) to 11.5GW. As part of the Dutch Climate Agreement, and in accordance with the Dutch North Sea Agreement, the cabinet will allocate new offshore windfarm areas for a total of 20-40GW for the period up to 2050. The Energy Outlook Scenarios foresee in a minimum production requirement of 38GW offshore wind energy by 2050 . This means that in addition to the $11.5 \mathrm{GW}$ already planned by 2030 , additional areas for $27 \mathrm{GW}$ are required (Minister EZK, 2020).

To achieve a balance between nature, energy production and food production, including spatial allocations, the government initiated a roundtable with important actors, led by an independent facilitator. This resulted in the so-called North Sea Agreement (NZA). Its outcomes were, among others, spatial allocations for construction of OWFs until 2030 and an expansion of MPAs (OFL, 2020). The development of new OWFs and the expansion of MPAs will impact fisheries in the Dutch EEZ. Inside windfarms and Natura 2000 areas fishing will be prohibited and the loss of gear impact may have a positive effect on the benthic community and bycatch of unwanted species in these areas. Because of the closure of such areas, fishers will need to move their activities to other areas, i.e. displace their effort. Some areas that remain open, may therefore face increased fishing pressure, that may negatively impact the benthic communities in or near the seabed as well as vulnerable species that get bycaught at higher rates in the areas open to fisheries than they were before. In addition, vessels may need to take a detour steaming towards their fishing grounds as most windfarms are closed for passage, leading to increased $\mathrm{CO}_{2}$ emission and costs. A special situation is that of Brexit. At the time when this study was commissioned, outcomes of the Brexit negotiations were still unclear. In a worst-case scenario, closure of the south western North Sea was foreseen (Hard Brexit). The UK waters are not part of the NZA, but are nonetheless important for the Dutch fishing fleet. Areas closures in the Dutch North Sea (NZA) and resulting from Hard Brexit will lead to fewer areas being available as fishing grounds. This will lead to direct and indirect impacts on the North Sea ecosystem

The impact of additional windfarms and expansion of the Natura 2000 areas on the displacement of the fishing fleet and its associated ecological impact is yet unknown. It is hypothesized that due to the closure of additional areas, fishing effort will increase in the remaining open areas (i.e. all fishing effort that was previously allocated in the closed areas will be moved to the remaining open areas), with associated negative impacts on the ecosystem. To counter this increase and associated negative ecosystem impacts in the remaining open areas, the NZA includes agreements on a decommissioning scheme for demersal fishing vessels (OFL, 2020). The responsibility for implementing this scheme lies with the Dutch ministry of Agriculture, Nature and Food Quality (Minister LNV, 2020).

Decommissioning may result in lower total annual fishing effort of the entire Dutch fleet and have a positive impact on ecosystem status. Crucial in the discussion on decommissioning is the role of the individual transferable fishing rights of the vessels that will be decommissioned. Since the mid 1980s, the catch rights for the commercially important species Dover Sole and Plaice are managed under a system of Individual Transferable Quota (ITQs) (Van Hoof et al., 2020). This means that, after decommissioning, ITQ ownership remains with the former vessel license holder, and can be leased or 
sold to vessels remaining active in the fishery and therefore be fished. Decommissioning itself therefore may not necessarily lead to an effort reduction, as the remaining fleet may increase their fishing effort to land (at least part of) the catches that were previously landed by the decommissioned vessels.

\subsection{Research question}

In this study, we assess the effects of fleet displacement as a result of spatial closures with and without a decommissioning scheme for the period up to 2030. Our main research questions are:

1. What is the impact on the ecosystem (defined by three different parameters, impact on benthos, $\mathrm{CO}_{2}$ emissions and bycatch) under different scenarios for additional spatial closures of fishing area resulting from the construction of OWF and expansion of Natura 2000 areas?

2. What are the ecological impacts of these additional spatial closures scenarios in combination with a decommissioning scheme?

We simulate seven spatial closure scenarios (Section 1.3) and evaluate the ecological impact by measuring three different indicators: 1 ) the change in benthic biomass in the Dutch EEZ, 2) the change in $\mathrm{CO}_{2}$ emission by the Dutch fishing fleet, and 3 ) the change in unwanted bycatch of fish and rays. We describe the design of the study and approach to calculate the indicators in Chapter 2 of this report.

Although the results will be presented with specific focus on the Dutch EEZ, fishing by the Dutch fleet takes place all over the North Sea. This means that area closures in the UK or German EEZ also have an impact on the distribution of the Dutch vessels. As such, all EU planned OWF and Natura 2000 areas in the North Sea have been taken on-board and displacement of effort applies to all open fishing grounds (including outside the Dutch EEZ).

We formulated the research questions and associated scenarios in close communication with the ministry of Agriculture, Nature and Food Quality, which commissioned the study. The study is funded under Policy Support Research Theme 'Nature-inclusive Fisheries' (project no. BO-43-023.02-004).

\subsection{Scenarios}

In total, we investigate seven scenarios (Table 1 ). These vary in the number of vessels active in the Dutch fishing fleet (i.e. with or without decommissioning), the area closed for fishing (existing OWFs, new OWFs, existing Natura2000 and new Natura2000 areas and Hard Brexit) and the ability to lease or sell quota from decommissioned vessels to remaining vessel owners.

The first scenario represents Status Quo and simulates the fishing fleet in its current condition and has access to areas that are open for fishing as of August 2020. This scenario is considered to be the reference for all the other scenarios to allow for like-with-like comparisons. In this scenario, effort within each grid cell is estimated using the average monthly 2015-2019 catch, Catch per Unit of Effort (CPUE) and average maximum monthly time spend fishing in each cell (see details in section 2). As a result, the Status Quo scenario is not an exact replica of fishing activity as observed in 2015-2019. This allows us to directly compare the Status Quo scenario to the other scenarios as all assumptions (except for area closures) are then identical. As such, results for other scenarios are expressed as percentage differences from the Status Quo scenario rather than presenting absolute outcomes. Making use of a Status Quo scenario also implies that all results are compared to a situation in the past, and do not illustrate a future outlook as the dynamics of the fishing fleets and target stocks have changed since, and will change in the future even without the spatial closures considered here.

Several offshore windfarms are already scheduled to be built in the Dutch EEZ in the coming years. Until $203011.5 \mathrm{GW}$ will be constructed and for 2050 the cabinet plans an increase to a minimum of 
38GW (Minister EZK, 2020). This study uses the spatial closures due to wind farms until 2030, which coincides with the North Sea Agreement's timeline. There are too many uncertainties for meaningful simulations until 2050. The impact of the addition of the year 2030 windfarms (scenario 2) on the ecosystem will be compared to the Status Quo scenario to illustrate how additions in closed areas impact the fisheries and the ecosystem.

\section{Table 1}

The different scenarios and the effects that are taken into account in each scenario. Between square brackets in the first column the abbreviated naming convention is shown.

\begin{tabular}{|c|c|c|c|c|c|}
\hline Scenario & $\begin{array}{l}\text { Effects taken into account } \\
\text { Decommissioning }\end{array}$ & New* OWF & New* N2000 & Hard Brexit & $\begin{array}{l}\text { Catch of } \\
\text { decommissionec } \\
\text { vessels removed }\end{array}$ \\
\hline $\begin{array}{l}\text { 1. Status Quo } \\
(2015-2019) \\
\text { [SQ] }\end{array}$ & - & - & - & - & $\mathrm{NA}^{1}$ \\
\hline
\end{tabular}

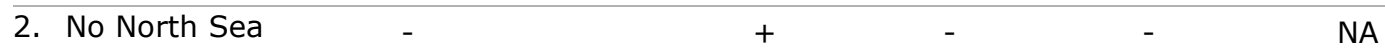
Agreement 2030

[Wind]

3. NZA $[N Z A]$

4. NZA \& decommissioning of vessels, fishing rights available [Decom NZA vessels]

\section{NZA \& decommissioning of vessels including their historical catch share \\ [Decom NZA vessels + catch $]^{2}$}

6. Hard Brexit

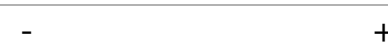

$+\quad+$

NA [Hard Brexit]

7. Hard Brexit \& decommissioning [Decom Hard Brexit vessels]

\footnotetext{
* For windfarms 'new' refers to new windfarms to be built in the period until 2030. For N2000, it refers to additional nature conservation closures as part of the Dutch North Sea Agreement (NZA).

${ }^{1} \mathrm{NA}$ indicates this variable is not applicable

${ }^{2}$ This scenario was included to represent the far end of the spectrum where under a decommissioning scheme the fishing rights previously used by decommissioned vessels are not exploited by the remaining fleet (for example, because of lack of capacity, crew, financial means to lease or buy quota, insufficient days in a year to fish the quota). Government policy is that decommissioning includes of the buy-back of vessels and withdrawal of licenses for gross registered tonnage and engine power $(\mathrm{kW})$ but that quota privately owned can be leased in or bought and therefore caught by remaining vessels.
} 

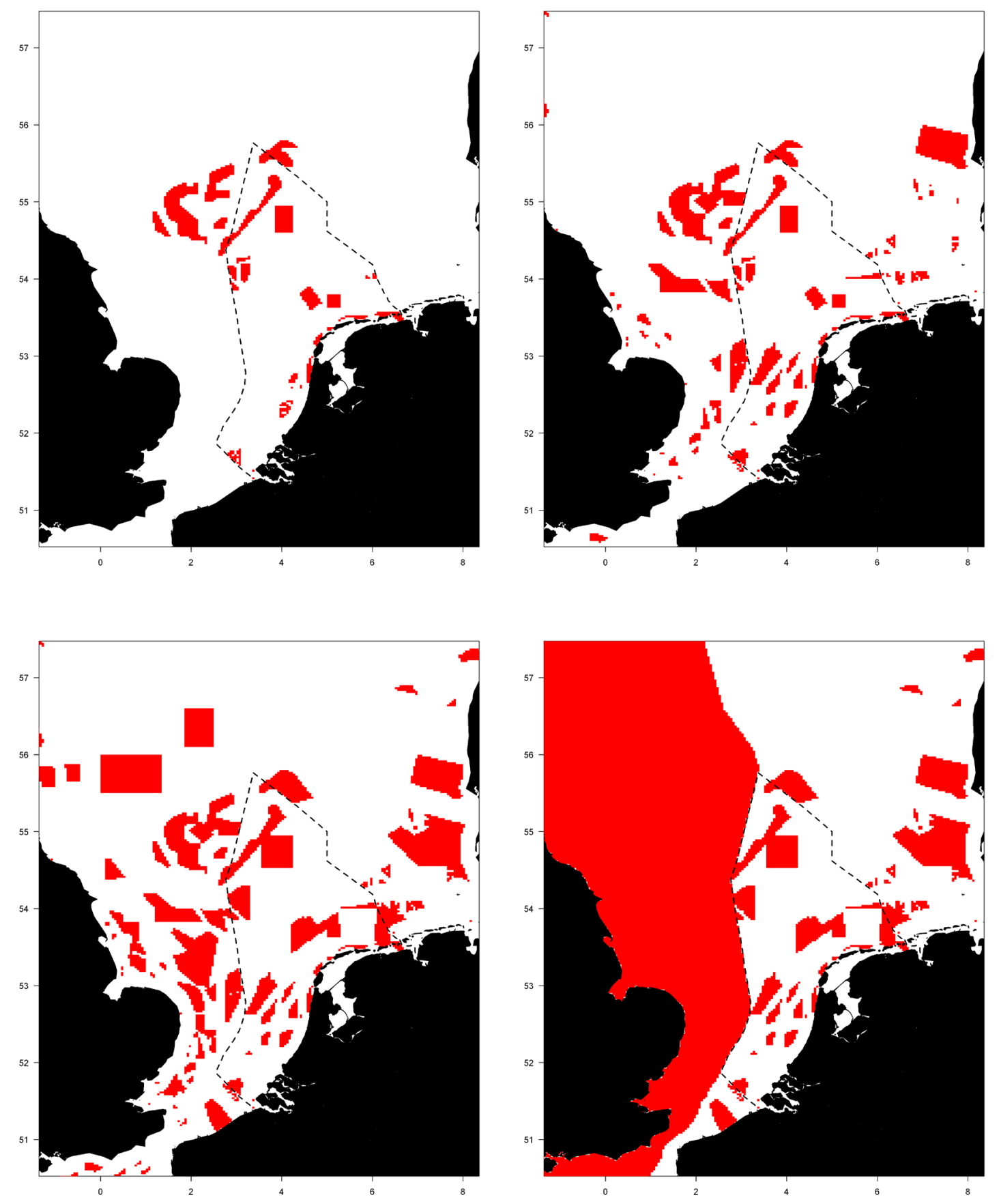

Figure 1 Top-left: In red, closed areas under the Status-Quo condition. Top-right: In red, closed areas under scenario 2 (wind). Bottom-left: In red, closed areas under scenario 3, 4 and 5 (additional closures of N2000 areas in scenarios NZA, NZA Decom vessels and NZA Decom vessels + catch). Bottom-right: in Red, closed areas under scenario 5 and 6 (closure of UK EEZ in scenarios Hard Brexit and Decom Hard Brexit vessels). Source: Maps provided by Ministry of Agriculture, Nature and Food Quality, June 2020.

The closed area as described in the NZA (scenario 3) increases substantially compared to the Status Quo situation. Less space is available for fisheries under this scenario and larger displacement of effort is to be expected. This result is compared to the Status Quo scenario but also to both the scenario in which part of the fleet will be decommissioned while the remaining vessels increase their effort to fish the decommissioned vessels' catch (scenario 4, i.e. total catch value stays the same as in the Status Quo scenario) and a scenario where the catch of the decommissioned vessels cannot be fished by the remaining fleet (scenario 5, i.e. total catch value decreases compared to the Status Quo scenario). 
A Hard Brexit scenario in which the UK EEZ will be fully closed for Dutch vessels is included to illustrate the large amount of displacement necessary to account for the loss of suitable fishing grounds on UK territory. This scenario is split up in two scenarios: closure of British water without decommissioning (scenario 6) and with decommissioning (of vessels only, catch and effort of the remaining vessels increases) (scenario 7).

\subsection{Study approach}

The study consists of a number of steps:

1. Defining assumptions underlying the displacement of effort under different spatial closure scenarios

2. Selection of vessels to decommission (if applicable)

3. Calculation of the impact on three indicators representing ecosystem impact

In step 1 we derive empirical relationships on effort allocation, footprints (i.e. effort per grid cell) and catch rates for different fleet segments. These relationships are used to project how effort is displaced if areas are closed where a fleet segment was active prior to closure.

In step 2, we assign a probability for decommissioning to each eligible vessel is. This is based on indicators which according to literature and expert judgement increase or decrease the probability of decommissioning. Furthermore, the 'decommissioning value' per vessel is determined. Based on these probabilities and values, 100 possible combinations of vessels opting for decommissioning are stochastically drawn.

In step 3, we determine the impact of the scenario (see section 1.3) on three ecological indicators. In scenarios Status Quo (1), Wind (2), NZA (3) and Hard Brexit (6), we assess the impact of possible changes in the behaviour of the current fleet on the three indicators. In scenario Decom NZA vessels (4), (Decom NZA vessels and catch (5) and Decom Hard Brexit (7), we use a bandwidth of the possible future fleets (current fleet minus the vessels possibly opting for decommissioning) based on the 100 theoretical decommissioning combinations (each combination calculated in step 2 lists a different set of fishing vessels that will be decommissioned) to understand possible changes in the behaviour of a smaller fleet and its impact on the three indicators.

We stress that the Hard Brexit scenario used in this study does not reflect the outcome of the actual Brexit agreement of 24 December 2020 (EU et al., 2020), when this study was near completion. When the study was commissioned by the Dutch Ministry of Agriculture, Nature and Food Quality, there was still no indication what the eventual outcome of the Brexit negotiations would be. It was therefore agreed to use the worst-case scenario, a Hard Brexit.

We emphasize that the design of the study is relatively simple and does not capture the complex nature of fishing behaviour and the impact of fishing on the ecosystem. However, no models are currently available to mimic the change in fishing behaviour, potential displacement and impact on the ecosystem as no wind farm or Natura 2000 areas with substantive area coverage have been closed yet to derive these behavioural rules from. As such, in this study, we had to make assumptions on how effort will be displaced, and how a local increase in fishing effort relates to changes in e.g. catch rates. The impact of these assumptions is discussed and where possible numerically investigated by evaluating alternative assumptions (i.e. sensitivity simulations). 


\subsection{Report structure}

In Chapter 2 we will discuss the research methodology. This includes our assumptions on effort displacement under the scenarios, selection of vessels to decommission in the modelling exercise and their buyout value, and the calculations of the three ecosystem indicators for the scenarios.

Chapter 3 presents the results of the drivers of decommissioning and subsequent impacts of decommissioning on benthos, $\mathrm{CO}_{2}$ emissions and by-catch for the different scenarios. The chapter concludes with a qualitative assessment of these results.

In chapter 4, we discuss the main results in the context of critical assumptions and outline the implications of the results and uncertainties. 


\section{Methodology}

\subsection{Data sources}

As a study area we outlined the North Sea (ICES division 4.a-c) and the eastern English Channel (ICES division 7.d) between 49 and $60^{\circ} \mathrm{N}$ latitude. We divided the area divided in a spatial grid with cells of 0.05 -degree longitude by 0.025 degrees latitude. The average area of the grid cells is $12 \mathrm{~km}^{2}$. All calculations are done at the level of these grid cells. Information on closed areas (both windfarms and Natura2000) was obtained from the Noordzeeloket (www.noordzeeloket.nl). Future plans for OWFs and Natura2000 areas outside the Dutch EEZ were obtained through the ICES working group on Spatial Fisheries Data (ICES WGSFD) that collate this information for research purposes. Future plans for Dutch waters were obtained via the ministry of Agriculture, Nature and Food Quality.

The following bottom trawling gears are included in the ecological assessment: beam trawls (TBB), otter trawls (OTB), twin/multi rig trawls (OTT), shrimp trawls (TBS), pulse trawls (PUL), Scottish seines (SSC), boat dredges (DRB) and mechanised dredges (HMD). Further size categorisation is applied to some of these gear types (see Table 4).

Vessel Monitoring System (VMS) and logbook data from the fleet under Dutch flag for the years 20152019 are used to derive empirical relationships on catch rates, footprint, steaming distances etc. For the calculation of the buyout value for individual vessels, we use data from the "Bedrijveninformatienet" (BIN) managed by Wageningen Economic Research and "VIRIS" data, edited by Wageningen Economic Research.

\subsection{Scenario development}

The seven scenarios outlined in Table 1, Chapter 1.3 were selected in cooperation between the research team and the ministry of Agriculture, Nature and Food Quality. Initially this included only 4 scenarios: the current numbers 1 (Status Quo), 2 (No North Sea Agreement, only windfarm closures 2030), 3 (North Sea Agreement: windfarms 2020 + additional nature conservation areas) and 5 (scenario 3 combined with decommissioning and catch). For the decommissioning scheme, we initially used the assumption that historic catches by the decommissioned vessels would not be fished by the remaining vessels. In discussions of initial results with the ministry, we concluded that it would not be realistic to assume that catch rights from decommissioned vessels would not at all be used by the remaining fleet. It was, however, questioned whether or not all historic catches of decommissioned vessels would be fished considering the remaining fleet capacity. We therefore included an additional scenario (the current scenario 4), where the historic catch share of the decommissioned vessels would be available and fished by the remaining fleet. Scenarios 4 and 5 hence represent two extremes on the continuum of decommissioning scenarios.

Following discussions of initial results with the ministry, we included scenarios 6 and 7, i.e., further closures due to Hard Brexit respectively with and without decommissioning, as part of the research question. As there was still no indication what the eventual outcome of the Brexit negotiations would be, it was agreed to use the worst-case scenario, a Hard Brexit, where all British waters would be closed for non-UK vessels. The Hard Brexit scenario used in this study therefore does not reflect the outcome of the actual Brexit agreement of 24 December 2020 (EU et al., 2020).

When the study was commissioned, Parliament still had to discuss the North Sea Agreement, including the option of decommissioning. The ministry of Agriculture, Nature and Food Quality, in order not to lose time, wanted to start preparations for a possible decommissioning scheme, including an ecological impact assessment. This is why, per request of the ministry, the fishing industry has not been involved 


\subsection{Defining assumptions underlying the effort displacement under different scenarios}

To calculate how effort could be displaced under different spatial closure scenarios we require information on:

1. The historic footprint of a fleet segment (by gear \& horsepower category),

2. The catch rates of a fleet segment for the main target species at all spatial locations in our study area

3. The total catch of a fleet segment per species

4. The visiting frequency and maximum time spent at fishing grounds

In addition, we need to make an assumption on how a fleet segment will respond if areas are closed. We consider three options: i) a fleet segment will maintain fishing with the same amount of effort as pre-closure, ii) a fleet segment will maintain the same quantity of fish landed as pre-closure, iii) a fleet segment will maintain the same value of the landed fish as pre-closure. Given the diversity of the targeted fish species and their price difference (e.g. plaice is on average $€ 2,38 / \mathrm{kg}$ compared to $€ 11,33 / \mathrm{kg}$ for Sole, 2019 prices), we considered that maintaining the total volume of catch was inappropriate (eliminating option $\mathrm{ii}$ ). Assuming that the availability of quota is the limiting factor for the activity of most fishers (and not the effort, eliminating option i) and that the value of landings reflects better the mixed fisheries targets of fishers in the absence of a full economic model accounting for the costs, we select option iii. Selecting option iii implies that the total value of the catch needs to be the same in scenario 1 (Status Quo) and in all other scenarios. Scenario 5 is an exception to this general approach where the value of the catch is reduced by the value of the catch from the decommissioned vessels.

\subsubsection{Historic footprint \& total catch}

Fishing effort and corresponding catches per grid cell are calculated by combining Vessel Monitoring by Satellite (VMS) data and mandatory logbooks from the VISSTAT database. VMS data contain information on vessel speed and vessel position, whereas the vessel logbooks provide information on catches by species, mesh size, gear, and vessel length and power. VMS and logbook data from 2015 to 2019 were extracted, including in total 366 unique vessels, with 300 to 313 unique vessels per year.

As vessels' speed profile typically shows a three-modal frequency distribution, speeds can be distinguished into steaming, fishing and floating (Poos et al., 2013). All vessel positions labelled as fishing are selected, while positions within the 6-miles zone of the coast are excluded to avoid assigning catches to harbour positions for vessels with engine power $>225 \mathrm{~kW}$. The data were subsequently interpolated following a method described in Hintzen et al. (2010), resulting in high resolution fishing tracks. The catches by species from logbook data are matched with and divided over the interpolated fishing positions (method: Hintzen et al., 2012).

We quantify fishing effort in three different ways:

- hours fished per month,

- $\quad$ surface area swept (in $\mathrm{km}^{2}$ ) per month, representing the area trawled by the gear thereby impacting the surface of the seabed,

- $\quad$ subsurface swept area (in $\mathrm{km}^{2}$ ) per month, representing the area trawled by the gear thereby impacting the subsurface of the seabed based on the penetration of the gear into the sediment (see Rijnsdorp et al. 2018 for a description of the methodology).

Calculations are performed with a monthly time-step to account for seasonal differences in the footprint of a fishery. 
Fishing effort is calculated for each vessel and grid cell and summed per month to reflect the total fishing effort of a vessel in each month (see Figure 2 for illustration purposes). A monthly mean is then calculated based on the five years of data (2015-2019). Hours fished per month can be taken directly from the VMS and logbook analysis. Surface and subsurface swept area per month are calculated following (Eigaard et al., 2016).

Similar to fishing effort, catch per species (in $\mathrm{kg}$ ) is calculated by summing the catches of each month for each vessel and in each grid cell. Then a mean monthly catch was calculated for species caught by the vessels based on the five years of data.
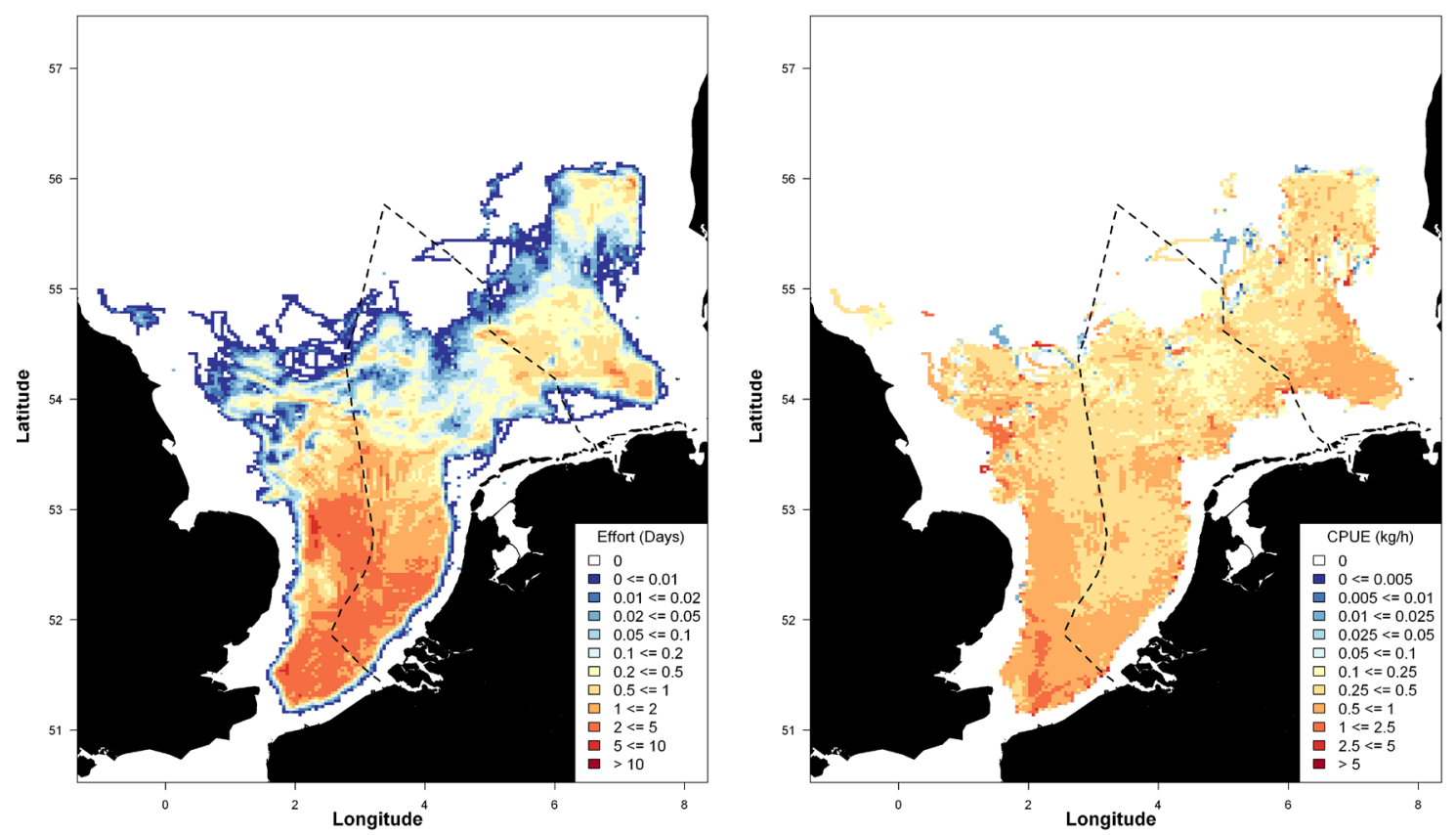

Figure 2 Left: Annual average effort of the pulse trawl fleet. Right: Annual CPUE $(\mathrm{kg} / \mathrm{h})$ of sole of the pulse trawl fleet.

\subsubsection{The catch rates of a fleet segment}

Catch Per Unit of Effort (CPUE) is calculated at fleet segment level (e.g. small beam trawls or large pulse trawls) by summing all catches of all vessels of a particular fleet segment and dividing by the sum of their effort (by month and grid cell). This CPUE represents average CPUE over a 5-year period over all vessels in a particular fleet segment. For illustration purposes, Figure 2 shows the annual average effort for one Dutch fleet segment (pulse), see also section 2.3.1. In the simulation, CPUE declines with effort, as has been observed for the Dutch beam trawl fleet in Rijnsdorp et al. (2011), which reflects a reduction of $20 \%$ in one days' worth of fishing ( 20 h per day). This CPUE decline reflects exploitation competition. This number was converted to a CPUE decline per additional $x$ percent of effort and amounts to roughly $0.128 \%$ CPUE decline per $1 \%$ effort increase. CPUE decline is calculated as $0.9905^{15.8} \times$ effort increase $0.9905^{15.8}$, where the 15.8 stands for the baseline hours fished per week, the effort increase is the increase in effort relative to the Status Quo scenario. Given the non-linear relationship, the CPUE decline as used in the simulation is close to, but not identical to what would follow from the equation above that depicts starting CPUE and CPUE at the end of the fishing activity.

We assume here that CPUEs are recovered to their initial value at the start of each month, suggesting that no fishing ground is trawled extensively for a full month and hence recovery of species distribution can take place in the area. The possible impact of crowding by other fleet segments not sharing target species is not considered here, nor is crowding of fishing vessels within a fleet segment (i.e. interference competition (Poos et al., 2007)) considered. We assume that crowding negatively impacts catch rates once predicted effort within a grid cell exceeds a full week of fishing per week (i.e. when the total effort is more than $80 \mathrm{~h}$ of fishing in one weeks' time). Analyses of the amount of fishing effort within grid 
cells, based on the 2015-2019 data, indicate that only a very small fraction of the grid cells contained such large fishing effort that an increase in crowding would be inevitable under any of the scenarios. Given this low fraction, we consider crowding to be of negligible effect in this study and hence this is not included.

We calculate the variability in effort and CPUE per fleet segment over the years 2015-2019 to indicate how much effort increase between years has been observed in the past. In the simulations, there is no theoretical limit on increases of effort in a grid cell. In reality there is. We therefore compare this historically observed variability between years to the effort changes we simulate to indicate how realistic a specific increase in effort may be.

\subsubsection{The visiting frequency and maximum time spend at fishing grounds}

Some fishing grounds are visited multiple times during a year. This implies that fishers have to steam to the fishing ground several times a year. Due to the displacement of effort, the number of times a fishing ground will be visited in a year may change. To estimate this visiting frequency we estimate the maximum time fishers stay on a specific fishing ground within a trip. If total effort to be allocated to a fishing ground exceeds this maximum time (constant within a grid cell), additional trips are needed, up to the point that the predicted effort can be realised leading to more $\mathrm{CO}_{2}$ emissions.

\subsubsection{Displacement of fishing effort}

Monthly effort displacement is calculated for each fleet segment separately. To calculate how much effort needs to be displaced, we assume that the total value of the landings by the entire fleet segment from the additional to be closed areas (dependent on the scenario and in comparison to the Status Quo scenario), has to be caught in the remaining open areas. Total value is derived from summing the value of all catches of all species in each of the grid cells in the footprint area (average effort per grid cell in a month averaged over the years 2015-2019). Value of the catch of e.g. Sole in a grid cell depends on the CPUE of Sole, the effort in that grid cell and the price of Sole in a specific month.

The displacement of fishing effort is calculated separately for each of the seven scenarios. Since the fleet remained constant in scenarios 1, 2, 3 and 6 (no decommissioning), only one set of displaced effort maps per fleet segment per month have to be calculated per scenario for those scenarios. For scenarios 4, 5 and 6, including decommissioning of part of the fleet, we calculate 100 different sets of displaced effort maps per month per scenario for the different decommissioning vessel combinations.

To illustrate how the underlying mathematics work out, we describe effort displacement with an example of the reallocation of effort of
the pulse fleet segment. We take the footprint (i.e. average effort per grid cell in a month averaged over the years 2015-2019) of the
pulse fleet. This footprint is scaled up or down such that the final result (same total catch value in closure scenarios as in the Status Quo
scenario) is met. The footprint in the newly closed areas is set to 0 and therefore, the effort in the remaining grid cells of the footprint
have to go up to compensate for the loss of catch value previously fished in the closed areas. This scaling factor is determined with a
build-in minimiser in R where we find the closest match between value of the top $95 \%$ of the target species of the pulse fleet (mainly
Sole, Plaice, Turbot, Brill) in the Status Quo condition and when taking the closures into account. Although we scale the entire footprint
(and hence not grid cell specific), the scaling procedure has highest weight on the species with the highest total value in the catch. This
implies that after effort is being scaled up or down, a good match for the value of each of the most important species is secured. No
perfect match can be obtained in this procedure as CPUEs differ per grid cell and the set of grid cells we're doing the calculation for
differs from the Status Quo situation. The scaling of effort is furthermore influenced by a declining CPUE for each species in each individual
grid cell with increasing effort. For every days' worth of fishing, CPUE declines with $20 \%$ from its initial value. At the beginning of each
month, the CPUE is reset again at its initial value.

Box 1 Example of how reallocation of effort for a fleet segment is calculated. 


\subsection{Selection of vessels to decommission}

The decommissioning scheme the Dutch ministry of Agriculture, Nature and Food Quality is considering would be applicable for demersal fishing vessels with a minimum length of $15 \mathrm{~m}$, belonging to the Dutch MFL1 ${ }^{1}$ segment. In this scheme, vessels, tonnage and kilowatts allowance will be permanently decommissioned.

\subsubsection{Probability of opting for the decommissioning scheme}

The decommissioning scheme is on a voluntary basis. Therefore, we do not know exactly in advance how many or which vessels will opt for the scheme and their characteristics. Historically, there were often either many more or fewer applicants for decommissioning schemes than forecasted (Hoefnagel et al., 2004, p.14). In order to assess the effect of the scheme on the ecological situation of the North Sea, we have to estimate which ships are likely to be opted for the scheme.

This is done by defining socio-economic motivating factors driving owners to voluntarily opt for their vessel for the scheme (Hoefnagel et al., 2004). The driving factors are carefully selected and weighted based on previous research and in a workshop with experts from Wageningen Economic Research and Wageningen Marine Research. The factors are quantified on ship-level with available data. A final probability between 0 and 1 is calculated for each ship based on the weight of the category and of the driving factor as decided on by experts.

A further elaboration on the influencing factors, the categories and their importance is provided in Annex A.

\subsubsection{Defining buyout value for each vessel}

Besides the probability that an individual vessel will be decommissioned, it is necessary to estimate the buyout value for each vessel. We assume that the considered decommissioning scheme will have a budget of 73 million euros (personal communication ministry of Agriculture, Nature and Food Quality). The sum of the selected group of vessels potentially being decommissioned and contributing to the ecological assessment, cannot exceed this budget. We stress that the buyout value as calculated in this exercise serves as input for the ecological assessment of the decommissioning scheme and should not be considered as a true buyout value on which the scheme itself can be based.

The buyout value for each vessel is calculated in accordance with a common calculation method used for decommissioning schemes (see: Quirijns et al., 2019; Turenhout et al., 2016a). This value represents the amount for which the owner is expected to voluntarily report the ship for decommissioning, irrespective of other factors contributing to such decision.

For the buyout value, the sum of the net profit and the income is multiplied by a capitalization factor of 7, to consider the loss in future profit. The capitalization factor represents the ratio between the value of an object (or right) and the expected annual profit from its use (Quirijns et al., 2019). Finally, the future alternative income of the vessel owner is deducted to control for the gains of future other employment, or:

- $\quad$ Buyout value $=(($ average net profit + share wage of the owner $)-$ alternative income $) *$ capitalization factor

For the calculation of the values, the following steps have been taken:

- The net profit of the vessel is calculated based on economic data from the "Bedrijveninformatienet" (BIN, managed by Wageningen Economic Research). For vessels within the panel dataset, this means the average net profit over the years 2015-2019. The year 2019 is an approximation based on the average of the past 4 years since data was not yet available. The profit of vessels not represented in the panel is calculated based on the

\footnotetext{
${ }^{1}$ Definition of MFL1: Part of the fleet that is allowed to fish on species which are subject to a quota, consisting of small-scale coastal fisheries $<12 \mathrm{~m}$, pelagic trawlers, cutters $>221 \mathrm{~kW}$, Eurocutters $<221 \mathrm{~kW}$ and small fisheries vessels.
} 
average daily fishing effort as retrieved from logbook data from 2015-2019 multiplied by the average daily net profit of vessels using the same fishing gear and settlings.

- The share wage of the owner is based on the average share wage (of owners being part of the crew) from the panel data per horsepower (hp) class (classification: 301-800hp, 801$1500 \mathrm{hp}$ and $>1500 \mathrm{hp}$ ). Vessel level data is not available. Share wage (or the Dutch deelloon) is a system in the Dutch fishery where crew members earn a share of the landing value for each day they sailed along (Zaalmink, 2018).

- The alternative income is based on the assumption that the owner will find other work after decommissioning. This only counts for owners who are part of the crew. The alternative income is set at the Dutch average income of $€ 36.500$ a year (Planbureau, Augustusraming 2020-2021, 2020). Owners of a company with multiple vessels do not sail along and therefore do not receive share wage. The share wage and alternative income are left out of the calculation for vessels belonging to a company with multiple vessels.

- The capitalization factor represents the relationship between the value of an object and the expected future profit. In previous decommissioning and expropriation schemes in fisheries and agriculture, the capitalization factor used was between 5 and 10 (Quirijns et al., 2019). In a voluntary decommissioning scheme, the capitalization factor is usually lower than in cases of expropriation (Taal, 2010). In this calculation, we use a capitalization scheme of 7 following consultation with the ministry of Agriculture, Nature and Food Quality at the start of the study.

Details and assumptions are further elaborated on in the Annex B.

\subsubsection{Simulation of decommissioning vessels}

We simulate the decommissioning scheme $\mathrm{i}$ by drawing vessels from the list of vessels that may voluntarily opt for decommissioning. The drawing of vessels is done a hundred times, leading to a hundred simulated decommissioning schemes. This approach gives us an idea of the range of possible groups of vessels that will most likely opt for decommissioning, while takings into account uncertainties regarding the vessels opting for decommissioning and associated effects on the ecological indicators. Vessels with a high probability of opting for decommissioning also have a high probability of being drawn, and vice versa. The 100 draws of vessels, taking probability into account, resulted in 100 ordered lists of vessels to be 'first in line' for decommissioning till 'last in line'. For each of these 100 draws, only the top $x$ vessels, with a combined decommission cost $<73$ million, are selected. If vessels are selected to be decommissioned, the space at sea they utilize is no longer taken into account when predicting effort displacement. In this case, catch rates (CPUE) are calculated based on the remaining vessels per fleet segment.

In the "decommissioning vessels" scenarios (NZA - 4 and Hard Brexit - 7), we assume that the catch rights of the decommissioned vessels will be available for the remaining fleet (via lease, selling of quota or because the decommissioning vessels leased in the quota they used). Hence, the catch value of the decommissioned vessels is distributed over the remaining fleet. In practice, this may turn out differently, for example, because of lack of capacity in the remaining to exploit the released quota, lack of financial means to lease or buy quota, or insufficient days in a year to fish the quota with the remaining fleet. We currently do not have the tools nor the information about current quota ownership to account for such factors in our simulations. Therefore, scenario 5 (Decom vessels + catch $-v$ ) represents the far end of the spectrum where under a decommissioning scheme none of the catch of the decommissioned vessels is fished by the remaining fleet. In this scenario, the quota corresponding to the catch of the decommissioned vessels is no longer available for the remaining fleet. We note that government policy is that decommissioning includes buy-back of vessel or demolition and withdrawal of licenses for gross registered tonnage and engine power $(\mathrm{kW})$. 


\subsection{Calculation of three indicators representing ecosystem impact}

We evaluate the impact of the fishery on the ecosystem based on three indicators that represent three potential impacts of closing areas and decommissioning of the fleet: 1) change in the relative state of the benthic invertebrate community, 2) change in $\mathrm{CO}_{2}$ emissions, and 3) change in unwanted bycatch of fish species and invertebrates. For these indicators, data and methodologies to calculate ecological impacts are available. Displacement of effort due to (additional) area closures will (for bottom-trawl gears) impact the benthic community in areas no longer fished and areas with increasing fishing effort. It will also lead to changes in catch composition including unwanted by-catch as fish populations are not heterogeneously distributed over the North Sea. Finally, displacement will impact steaming time and hence $\mathrm{CO} 2$ emissions (with indirect effects on ecology through associated climate change). The indicators are calculated for all scenarios (Table 1), allowing for a comparison between the state of the indicators under Status Quo condition and the remaining scenarios in which additional areas are closed.

\subsubsection{Change in benthic biomass in the Dutch EEZ}

To assess how the redistribution of fishing effort may affect the benthic community, we calculate for each scenario the Relative Benthic State (RBS). This is the biomass of the benthic community (B) as a fraction of the maximum potential biomass of the community when no trawling takes place (K). The RBS is then calculated as $B / K$ and varies between 0 and 1 . Low values indicate a low biomass of the benthic community compared to when no fishing would take place. In other words, a low RBS indicates that the benthic community is highly impacted by fishing.

The method was developed by Hiddink et al., 2017, 2019; Pitcher et al. and 2017; Rijnsdorp et al., 2018, 2020a. It is based on general, mechanistic assumptions about population dynamics (therefore also referred to as the 'PD (population dynamics method') and the longevity composition of the benthic community.

The RBS combines a model developed by Rijnsdorp et al. (2018), where biomass of benthos samples from the North Sea and the Eastern English Channel were modelled against longevity, trawling, habitat characteristics of the seabed and a measure of natural disturbance on the seabed and the PD approach. However, as the natural disturbance data used by Rijnsdorp et al. are not publicly available, the model cannot be used. Therefore, a new model to estimate biomass needs to be constructed with another set of variables representing natural disturbance (mean tidal velocity and mean orbital velocity from Wilson et al., (2018). We set up a range of models with different combinations with and without the natural disturbance variables obtained from Wilson et al. (2018). Based on the Bayesian Information Criterion, we consider the model without the new natural disturbance variables best. The model parameters of the final model are presented in Table 2. By taking these parameters and the habitat data of the entire North Sea, we calculate the potential biomass of the benthic community for each grid cell in the North Sea in the case of no trawling (i.e. the $\mathrm{K}$ parameter in RBS $=\mathrm{B} / \mathrm{K}$ ). Habitat data (percentage of mud and gravel) for the entire North Sea were taken from Wilson et al. (2018).

\section{Table 2}

Parameters of the fixed effects of the final model of the cumulative proportional biomass of benthos against trawling, habitat and longevity. Longevity and trawling were log-transformed.

\begin{tabular}{lccc} 
Parameter & Estimate & Standard error & P-value \\
\hline Intercept & -5.493 & 0.293 & $<0.001$ \\
\hline $\log$ (longevity) & 3.423 & 0.164 & $<0.001$ \\
\hline $\log$ (trawling intensity) & 0.110 & 0.061 & 0.073 \\
\hline Mud \% & 0.018 & 0.003 & $<0.001$ \\
\hline Gravel \% & 0.022 & 0.012 & 0.068 \\
\hline log(longevity):Gravel \% & -0.018 & 0.006 & 0.005 \\
\hline
\end{tabular}


The fraction of benthic biomass lost due to mortality caused by trawling is called 'depletion'. The depletion depends on the penetration of the gear into the sediment, and has been estimated for a range of gears by (Hiddink et al., 2017) (Table 3). For Scottish seines (flyshoot) and shrimp trawls, we assume a similar depletion as for otter trawls, whereas we assume the depletion for the pulse trawl to be $50 \%$ of that of a beam trawl (Rijnsdorp et al., 2020b). The depletion value is multiplied with the corresponding trawling frequency of each depletion gear group in each grid cell and then summed (Table 3). Trawling frequency is the sub-surface area that is swept in a year by the trawling gears as a ratio of the total area in a grid cell. It is also called the 'swept area ratio'.

\section{Table 3}

Depletion values per gear group, and gears included in each gear group. Depletion values for TBB, OT and TD are taken directly from Hiddink et al. (2017). For Scottish seines and shrimp trawls, a similar depletion as for otter trawls was assumed. Following Rijnsdorp et al. (2020b), we assumed the depletion of the pulse gear to be half of the value of the beam trawl gear group.

\begin{tabular}{lll}
\hline Depletion gear group & Depletion & Gears \\
TBB - beamtrawl & 0.14 & TBB \\
\hline OT - otter trawl & 0.06 & OTB, OTT, TBS, SSC \\
\hline TD - dredge & 0.20 & DRB, HMD \\
\hline PUL - pulse trawl & 0.07 & PUL \\
\hline
\end{tabular}

The calculation of the longevity-biomass composition of the benthic community with fishing effort under the different situations (i.e. the $B$ parameter in RBS = B/K) uses the trawling frequency, the depletion value and the recovery rate of the benthos into account, which is based on the longevity of species (Hiddink et al., 2019). We then calculate the RBS for all grid cells in each scenario based on the total annual fishing effort of all fleets combined.

\subsection{2 $\mathrm{CO}_{2}$ emissions by the Dutch fishing fleet}

We use the same interpolated data for the effort and catch information to calculate the distance that vessels travel to the fishing grounds. For each individual trip, we calculate the travelled distance separately for steaming and fishing activities. We then distribute the distance travelled while steaming over the grid cells where the vessel fished. For example, if a vessel steams $200 \mathrm{~km}$ in and $200 \mathrm{~km}$ out to a specific fishing ground and it visits 20 different grid cells while fishing, each of these 20 grid cells account for $20 \mathrm{~km}$ of steaming. We consider this the cost of steaming per fished grid cell (in $\mathrm{km}$ ). We average these steaming distances over all trips, by grid cell, month and fleet segment and hence represents an average distance steamed per trip for a whole fleet segment, regardless of their departure harbour (Figure 3 left). As we are comparing relative changes between the scenarios, departure harbour is less relevant for the analyses.

If, based on the interpolated data, it turns out that to fish in a specific grid cell, a vessel would have crossed a windfarm area, detour costs are calculated. For each trip that crosses one or more windfarm areas, we enlarge the total steaming distance with half the circumference of the largest windfarm on its route. As steaming through $\mathrm{N} 2000$ areas is often allowed, we only add a distance for windfarm areas. When no vessel crosses a windfarm area on its way to a specific fishing ground (i.e. grid cell), the detour costs are zero (Figure 3 right). Only for the Status Quo scenario a different detour regime is in place as fewer windfarm areas are closed.

$\mathrm{CO}_{2}$ emissions are based on a conversion of fuel use ( $1 \mathrm{~L}$ of diesel results in $4.16 \mathrm{~kg}$ of $\mathrm{CO}_{2}$ ) to $\mathrm{CO}_{2}$. Fuel use is directly related to time spent steaming and time spent fishing. Time spent fishing is obtained per grid cell from the effort after displacement. To convert time spend to km fishing we require average fishing speeds for each of the fleet segments. The distance steamed to get to a certain grid cell are converted to litres of diesel making use of average diesel consumption per hour and average speed of a vessel while steaming / fishing (see Table 4). We calculate $\mathrm{CO}_{2}$ emissions on a monthly basis and thereafter summed over the whole year. 
Total emission is derived from summing $\mathrm{CO}_{2}$ emitted through steaming and through fishing over all grid cells.
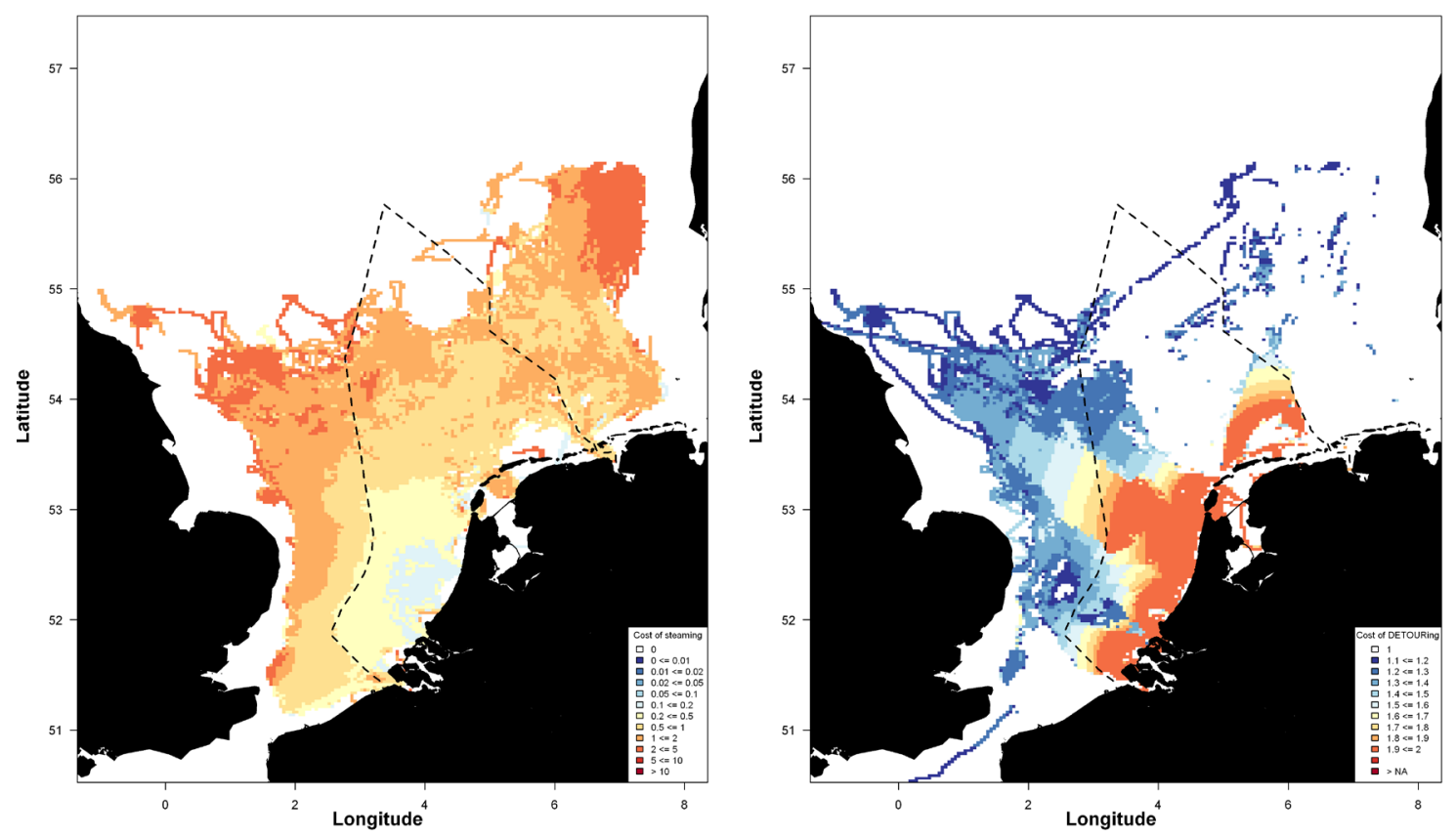

Figure 3 Left: Average cost (in $\mathrm{km}$ ) of steaming of the pulse trawl fleet. Right: Cost of detour expressed as a multiplication factor to the normal cost of steaming to a fishing ground. Areas in white have no additional detour cost.

\section{Table 4}

Key characteristics of fleet segments to calculate $\mathrm{CO} 2$ emission from distances fished and steamed.

\begin{tabular}{lccccc} 
Fleet segment & Subgroup & $\begin{array}{c}\text { Average fishing } \\
\text { speed }\end{array}$ & $\begin{array}{c}\text { Average steaming } \\
\text { speed }\end{array}$ & $\begin{array}{c}\text { Fuel use fishing } \\
\left(h^{-1}\right)\end{array}$ & $\begin{array}{c}\text { Fuel use steaming } \\
\left(h^{-1}\right)\end{array}$ \\
\hline OTB & Small & 3.04 & 8.08 & 85 & 30 \\
\hline PUL & Small & 4.76 & 8.5 & 72 & 30 \\
\hline TBS & & 3 & 7.74 & 43 & 30 \\
\hline PUL & Large & 4.94 & 10.36 & 168 & 116 \\
\hline TBB & Large & 6.1 & 11 & 274 & 116 \\
\hline TBB & Small & 4.58 & 9.58 & 56 & 30 \\
\hline SSC & Large & 1.28 & 9.8 & 85 & 116 \\
\hline OTT & Small & 3 & 8.04 & 85 & 30 \\
\hline HMD & & 0.36 & 7.56 & 85 & 30 \\
\hline OTB & Large & 3.1 & 9.08 & 87 & 116 \\
\hline SSC & Small & 1.54 & 9.3 & 69 & 30 \\
\hline DRB & Small & 3.4 & 9 & 85 & 30 \\
\hline OTT & Large & 3.1 & 9.08 & 87 & 116 \\
\hline
\end{tabular}

* Codes in alphabetical order: DRB = boat dredges; HMD = mechanised dredges; PUL = pulse trawls; OTB = otter trawls; $\mathrm{OTT}=$ twin trawls; TBB = beam trawls; TBS = shrimp trawls; SSC = Scottish seines (flyshoot). 


\subsubsection{Change in unwanted bycatch}

Calculation of change in unwanted bycatch is based on predictions of CPUE of unwanted bycatch / undersized species by a spatial statistical model (Brunel et al. 2019) for Dab, Plaice, rays, Sole, Turbot and Whiting. The statistical model fits discard and unwanted bycatch observer data of Dutch vessels and corrects for spatial and temporal correlation in this dataset. For each grid cell a prediction of CPUE for a range of species is available. Total catch of unwanted bycatch / undersized species is obtained by multiplying the effort as obtained after displacement per grid cell with these CPUE predictions per species and grid cell and summing over all grid cells inside the EEZ. The CPUE predictions are available for four different gear-vessel size combinations: pulse vs tickler chain and small vs large gear width (see Figure 4 for an example of the small beam trawl fleet). Insufficient data is available for other gears. Therefore otter trawlers and shrimp fishers are linked to pulse data, and flyshoot and dredge to tickler chains, based on expert judgement of the impact these gears have on unwanted bycatch species related to gear size and weight to the nearest available gear-width combination.

We calculate bycatch on an annual basis and therefore monthly effort distributions for each of the different fleet segments are summed. Given that most bycatch species do not have a quota or relate to species for which the quota have not been fully exploited in recent years, bycatch is calculated post-hoc and has hence no impact on the decision where to displace effort to.

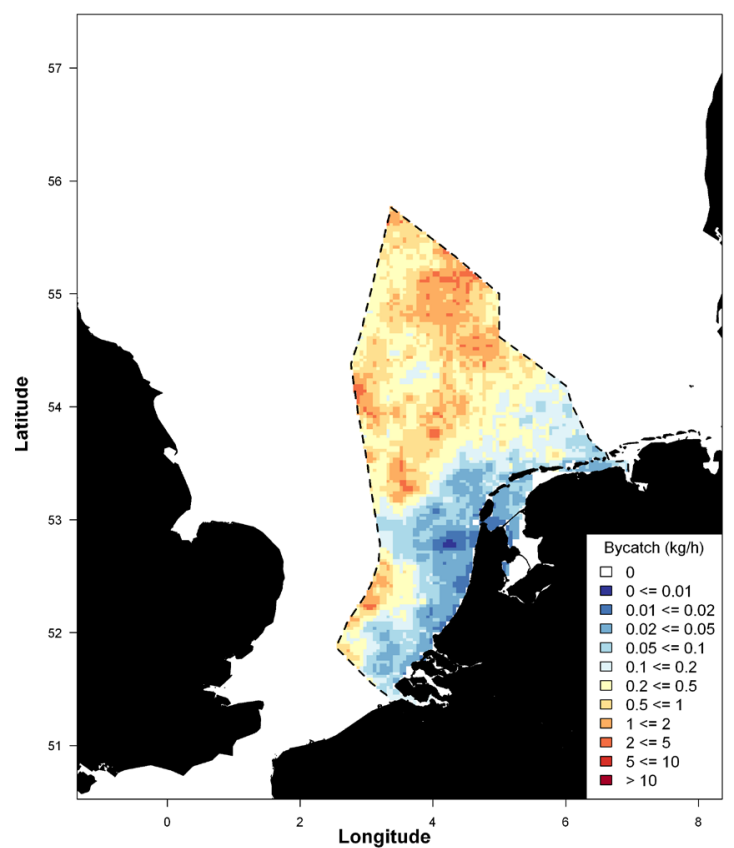

Figure 4 Unwanted bycatch ( $\mathrm{kg} / \mathrm{hour}$ ) for ray species in the Dutch EEZ for the small beam trawl fleet (with tickler chains). 


\section{Results}

We present our results for all scenarios in comparison to the Status Quo condition (scenario 1) and between scenarios similar in design (e.g. in terms of decommissioning assumption). We first present the results of the drivers of decommissioning so that subsequently, we can focus on the ecological impact results. Results for each scenario must be interpreted based on the fishing patterns of the fleet over the years 2015-2019.

\subsection{Simulation of drivers for decommissioning}

When we combine the data on all indicators of each vessel with the weights developed in the workshop with fisheries experts (see section 2.4.1 and Annex A), we get the final probability of decommissioning for each vessel. The vessel that is least likely to opt for decommissioning has a probability of $9 \%(0.09)$. The most likely vessel to opt for decommissioning has a probability of $45 \%$ $(0.45)$ to be decommissioned. The average vessel has a probability of around $24 \%(0.24)$ to be decommissioned (Figure 5). The calculated buyout values are between $€ 89,647$ and $€ 8,000,000$ with an average of around $€ 2.19$ million (see Annex B).

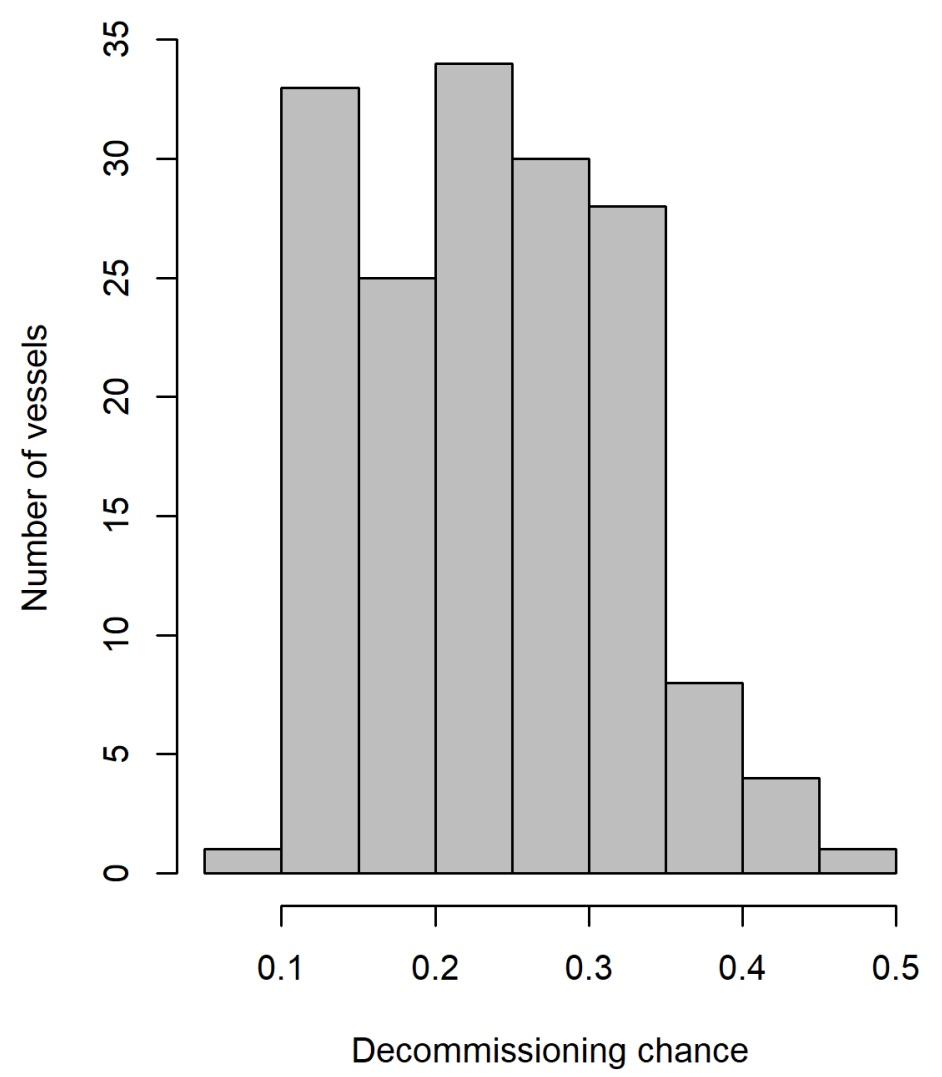

Figure 5 Frequency distribution of the decommissioning probability of vessels.

On average 30 vessels are drawn in a simulation; the minimum number of vessels being 24 and the maximum 37. The majority of vessels in each simulation are large pulse trawlers, with a median of 11 vessels in each simulation (Figure 6). On average four large beam trawlers and four trawlers that also 
fish for shrimp are drawn, whereas most other gear types are drawn only once or twice in each simulation (Figure 6).

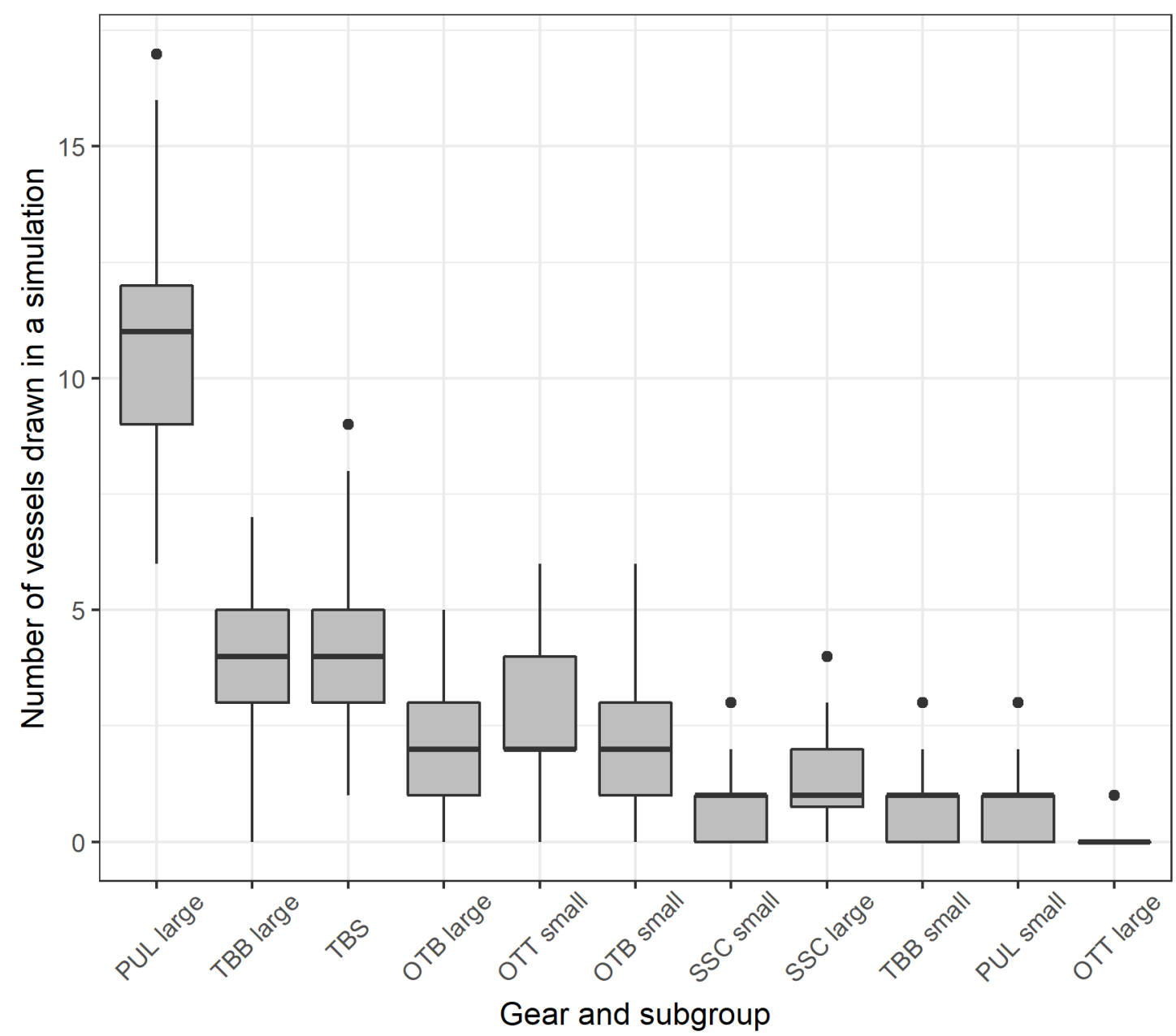

Figure 6 Variation in the number of vessels drawn in the simulations of the decommissioning scheme for each gear and corresponding subgroup. Black thick line in each bar is the median, upper and lower line of the boxes the upper (75th) and lower (25th) quartile and the end of the lines the minimum and maximum. Dots represent outlying values.

\subsection{Effort displacement}

Table 5 shows for each of the fleet segments how much of the effort was in the areas to be closed relative to the total effort (i.e., had the areas remained open, how much effort would have been allocated in these areas), all based on the Status Quo condition. This is a first indication of how much effort needs to be displaced to the remaining open areas. The additional planned offshore wind farm areas until 2030 [scenario Wind] will result in effort displacement by all fleet segments but mostly to a minor extent. The impact on the shrimp fleet (TBS) is highest as many additional area closures (windfarms, NZA) areas are to north of the Wadden Sea islands. The extra spatial closures planned under the NZA and Hard Brexit scenarios do, however, not affect the shrimp fleet much harder than other fleets, while the proportion of effort to be displaced increases for all other fleets. The large beam trawl fleet (both pulse and tickler chains) is affected by the closures under the Wind scenario at about $15 \%$ of its Status Quo effort (2015-2019) and to increasing extent under the NZA and Hard Brexit scenario with up to $51 \%$ of their footprint coverage being closed for fishing. The pulse fleet in general is expected to displace most of their effort under the Dutch plans for the North Sea (i.e. scenario Wind and NZA). The flyshoot fishery is mainly affected under the Hard Brexit scenario as they have a large fishery in the very southern part of the North Sea. 


\section{Table 5}

Fraction of effort allocated under the Status Quo scenario in the areas closed under the Wind, NZA and Hard Brexit scenarios. Numbers represent the fraction of total effort to be displaced in each scenario

\begin{tabular}{ccccc} 
Fleet segment & Subgroup & Wind & NZA & Hard Brexit \\
Gear & & 0.18 & 0.18 & 0.18 \\
\hline HMD & Small & 0.07 & 0.12 & 0.20 \\
\hline OTB & Large & 0.09 & 0.14 & 0.33 \\
\hline OTB & Small & 0.07 & 0.10 & 0.19 \\
\hline OTT & Small & 0.10 & 0.23 & 0.25 \\
\hline PUL & Large & 0.15 & 0.23 & 0.51 \\
\hline PUL & Large & 0.05 & 0.11 & 0.40 \\
\hline SSC & Small & 0.12 & 0.16 & 0.54 \\
\hline SSC & Large & 0.10 & 0.14 & 0.22 \\
\hline TBB & Small & 0.04 & 0.08 & 0.12 \\
\hline TBB & & 0.16 & 0.22 & 0.22 \\
\hline TBS & S &
\end{tabular}

* Codes in alphabetical order: HMD = mechanised dredges; PUL = pulse trawls; OTB = otter trawls; OTT = twin trawls; TBB $=$ beam trawls; TBS $=$ shrimp trawls; SSC $=$ Scottish seines (flyshoot).

After effort displacement, as simulated in this study, the effort that is needed to maintain equal catch value compared to the Status-Quo situation is presented in Table 6. This table thus shows how much additional effort is needed within each fleet segment to maintain revenue at the same level as in the Status-Quo condition. This change is driven by the relative level of CPUE in the closed areas compared to the CPUE in the open areas, as well as the decline in CPUE at each of the fishing grounds due to increased repeated trawling at those grounds.

\section{Table 6}

Relative effort that is needed to maintain revenues of each fleet compared to the Status Quo scenario. Colour scheme based on point or median estimates for all scenarios. Red indicates an increase in effort while blue indicates a decrease.

\begin{tabular}{|c|c|c|c|c|c|c|c|}
\hline \multicolumn{8}{|c|}{ Fleet segment } \\
\hline Gear & Subgroup & Wind & NZA & Hard Brexit & $\begin{array}{c}\text { Decom NZA } \\
\text { vessels }\end{array}$ & $\begin{array}{c}\text { Decom NZA } \\
\text { vessels + } \\
\text { catch }\end{array}$ & $\begin{array}{c}\text { Decom Hard } \\
\text { Brexit } \\
\text { vessels }\end{array}$ \\
\hline HMD & & 1.03 & 1.03 & 1.03 & [1.03 - 1.03] & {$[1.03-1.03]$} & {$[1.03-1.03]$} \\
\hline ОТВ & Small & 1.01 & 1.01 & 1.07 & $\begin{array}{l}{[0.86-} \\
1.24]\end{array}$ & {$[0.70-1.00]$} & {$[0.91-1.3]$} \\
\hline OTB & Large & 1.01 & 1.01 & 1.07 & {$[0.89-1.20]$} & {$[0.53-1.01]$} & {$[0.94-1.3]$} \\
\hline OTT & Small & 1 & 0.99 & 1 & {$[0.90-1.06]$} & {$[0.69-0.98]$} & {$[0.89-1.07]$} \\
\hline PUL & Small & 1 & 1.02 & 1.02 & {$[0.98-1.06]$} & {$[0.70-1.02]$} & {$[0.98-1.05]$} \\
\hline PUL & Large & 0.99 & 1.02 & 1.13 & {$[0.98-1.07]$} & {$[0.71-0.86]$} & [1.09-1.18] \\
\hline SSC & Large & 0.99 & 0.99 & 0.99 & {$[0.93-1.02]$} & {$[0.60-0.99]$} & {$[0.93-1.04]$} \\
\hline SSC & Small & 1.02 & 1.02 & 1.09 & [0.95 - 1.09] & {$[0.58-1.02]$} & {$[0.98-1.21]$} \\
\hline TBB & Large & 0.99 & 0.99 & 0.98 & [0.95 - 1.04] & {$[0.68-0.88]$} & {$[0.93-1.03]$} \\
\hline TBB & Small & 1 & 0.98 & 0.95 & {$[0.89-1.39]$} & {$[0.62-0.98]$} & {$[0.87-1.36]$} \\
\hline TBS & & 1 & 1 & 1 & {$[1.00-1.01]$} & [0.93-0.98] & {$[1.00-1.01]$} \\
\hline
\end{tabular}


Strikingly the results in Table 6 indicate that in some instances less effort seems to be needed to maintain total catch value for those fleets that fish further offshore (such as the large pulse and beamtrawl fleet and flyshoot fishery) with increasing surface area closed (from scenario Wind to NZA to Hard Brexit, Table 5). This is counter-intuitive and suggests that the current fishing fleet could fish the same value with less effort. To explore this would require further qualitative study and incorporation of findings in displacement models, but are likely related to historic preferences for fishing locations (personal knowledge about fishing grounds) combined with other behavioural choices fishers make at sea. These findings are further discussed below. The differences in effort needed vary only to a minor extent under the Wind and NZA scenario and under the Hard Brexit scenario almost all fleet segments require more effort to catch the same amount. For a number of fleet segments, the effort needed remains more or less the same as in the Status Quo scenario. This result implies that the negative effect of increasing effort at a fishing ground (i.e. decrease in CPUE) is countered by moving the fishery to fishing grounds with higher CPUE.

When part of the fleet is decommissioned, the surface footprint of the remaining vessels (i.e., the area visited by the remaining vessels) reduces. This results in an even higher effort allocation in areas where these vessels go. In a way, this implies that those fishing areas that were only fished by the vessels that get decommissioned, turn into unfished areas. The bandwidth of these results indicates that reductions but also increases in effort may be needed, depending on the specific set of vessels that will be decommissioned. This is especially striking for the small beam trawl fleet that may need up to an additional 39\% of effort in the Decommissioning NZA vessels scenario. It is to be expected that the results from the NZA and Decommissioning NZA vessels scenarios, but also the Hard Brexit and Decommissioning Hard Brexit vessels scenarios have similar median values (as represented by the colour coding in the table).

When the catch of those vessels that get decommissioned is excluded from the analyses [Decom NZA vessels + catch in Table 6], the required effort is substantially reduced and is always lower or equal to the Status-Quo scenario (except for dredge fishery that is not affected by decommissioning) and therefore also lower than the Decommissioning NZA - vessels scenario.

\section{Table 7}

Average additional effort factor at each fishing ground (i.e. grid cell) for each of the fleet segments after reallocation of the effort from closed grid cells. Values below 1 mean a decrease in effort, value of 1 means a stable effort and value above 1 mean an increase in effort. Median values are used for the Decommissioning scenarios. Red indicates an increase in effort while blue indicates a decrease.

\begin{tabular}{|c|c|c|c|c|c|c|c|}
\hline \multicolumn{8}{|c|}{ Fleet segment } \\
\hline Gear & Subgroup & Wind & NZA & Hard Brexit & $\begin{array}{c}\text { Decom } \\
\text { NZA } \\
\text { vessels }\end{array}$ & $\begin{array}{c}\text { Decom } \\
\text { NZA } \\
\text { vessels + } \\
\text { catch }\end{array}$ & $\begin{array}{c}\text { Decom } \\
\text { Hard } \\
\text { Brexit } \\
\text { vessels }\end{array}$ \\
\hline HMD & & 1.26 & 1.26 & 1.26 & 1.26 & 1.26 & 1.26 \\
\hline ОТВ & Small & 1.09 & 1.15 & 1.34 & 1.14 & 1 & 1.34 \\
\hline ОТВ & Large & 1.11 & 1.17 & 1.6 & 1.16 & 0.95 & 1.6 \\
\hline OTT & Small & 1.08 & 1.1 & 1.23 & 1.1 & 0.96 & 1.22 \\
\hline PUL & Small & 1.11 & 1.32 & 1.36 & 1.32 & 1.17 & 1.36 \\
\hline PUL & Large & 1.16 & 1.32 & 2.31 & 1.32 & 1.03 & 2.29 \\
\hline SSC & Large & 1.04 & 1.11 & 1.65 & 1.1 & 0.94 & 1.65 \\
\hline SSC & Small & 1.16 & 1.21 & 2.37 & 1.21 & 1.05 & 2.37 \\
\hline TBB & Large & 1.1 & 1.15 & 1.26 & 1.14 & 0.91 & 1.26 \\
\hline TBB & Small & 1.04 & 1.07 & 1.08 & 1.05 & 0.92 & 1.07 \\
\hline TBS & & 1.19 & 1.28 & 1.28 & 1.28 & 1.23 & 1.28 \\
\hline
\end{tabular}


Combining the results of table 5 and 6 gives insight in the additional effort to be allocated within each grid cell. The result of this combination is given in Table 7. The result is affected by the surface area closed for each of the fleet segments, the loss of important and unimportant fishing grounds and the reduction in CPUE at fishing grounds. This shows that under the Wind scenario, the increase in effort at each individual fishing ground to maintain similar catches is relatively small, but does go up $16 \%$ for large pulse vessels and small flyshoot, to $19 \%$ for the shrimp trawl (and $26 \%$ for HMD). Under the NZA scenario, this increase goes up to $32 \%$ for the pulse fleets while under the Hard Brexit scenario this increase goes towards $36-131 \%$ for the pulse fleets, $65-137 \%$ for the flyshoot and $34-60 \%$ for the otter trawlers respectively.

On average, decommissioning has a minimal effect on the local effort change under the NZA scenario (comparing the NZA and Decommissioning NZA vessels scenarios in Table 7). It shows that for almost all fleet segments the required fishing effort in each grid cell goes down or stays the same. There is, however, considerable variation around that interpretation given the bandwidth in Table 6 . We see the same effect when comparing the Hard Brexit and Decommissioning Hard Brexit vessels scenarios.

When catch of decommissioned vessels is not fished by the remaining fleet under the Decom NZA vessels + catch scenario, the net effort to be allocated within each fishing ground is more or less the same or decreases for most fleet segments in comparison with the Status Quo scenario. Only the dredge (1.26 in Table 7) and shrimp trawlers (1.23 in Table 7) require a substantial increase in effort in the remaining open areas they are accustomed to fish in.

Critical in the interpretation of these results is whether or not it is practically feasible to increase fishing effort by the existing fishing fleet at the fishing grounds; in other words, are we predicting effort increases never observed before? To address this question, we evaluate the average effort variability on a fishing ground for the different fleet segments. We do this separately for 11 different CPUE classes as it is hypothesised that fishing grounds associated with higher CPUEs are more important for a fleet segment than areas with lower CPUEs.

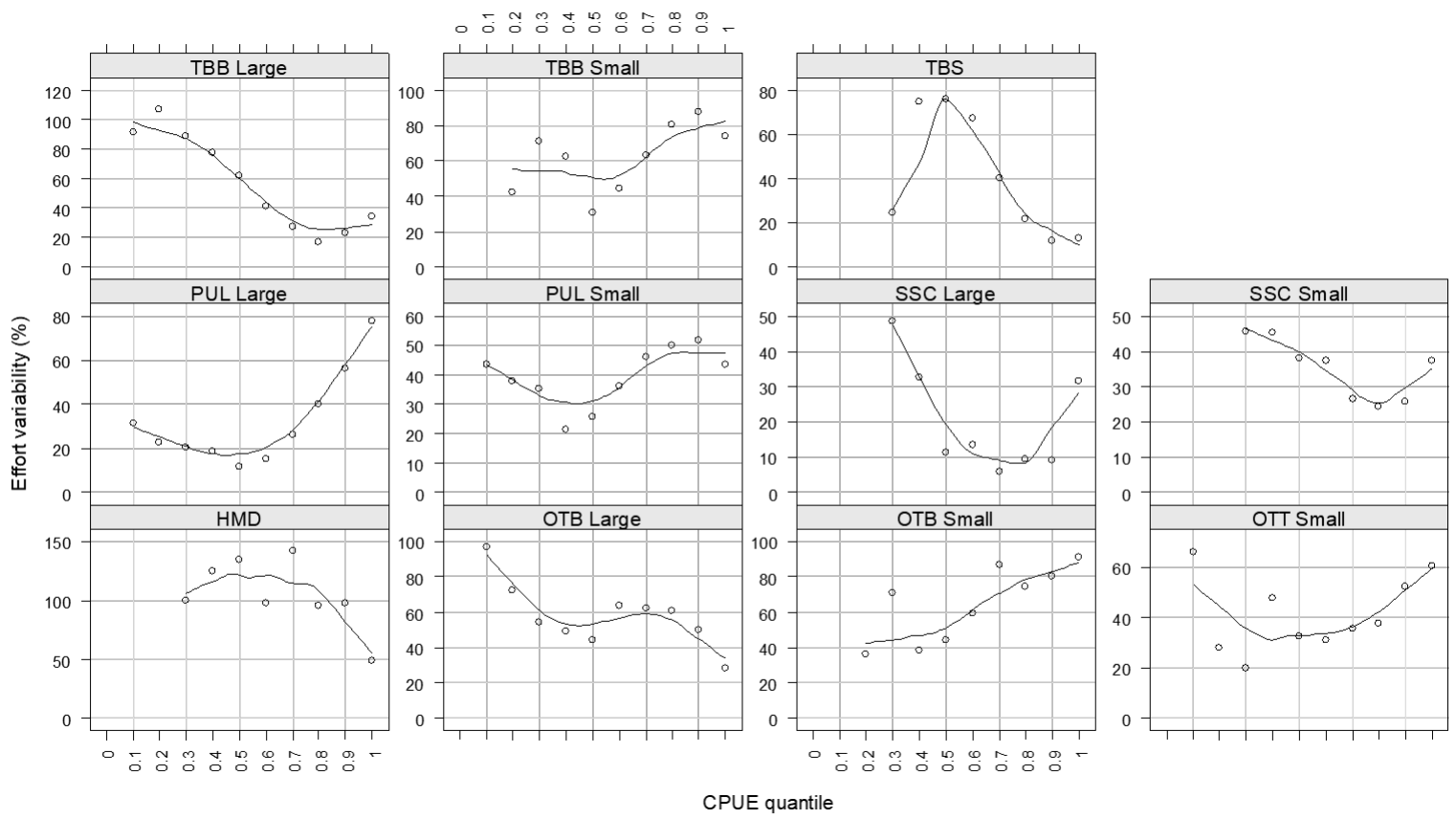

Figure 7 Variability in effort per fleet segment and calculated for up to 11 different CPUE classes. Line represents a smoother. Points represent the actual calculated variabilities

The variability (average relative difference with the long-time average) in effort between years in grid cells varies considerably among fleets. Figure 7 shows the variability in total effort for up to 11 different CPUE classes (ranked from low CPUE class till highest CPUE class). At higher CPUE classes, for large beam trawl, shrimp, otter trawl and flyshoot, variability is limited to $10-20 \%$ while for smaller 
beam trawls and the pulse trawlers variability in effort at fishing grounds with higher CPUEs increases up to $40-80 \%$. All fisheries, shrimp trawlers and flyshoot excluded, have a minimum variability at or greater than $20 \%$. When we contrast these variability numbers (in percentages) to the results presented in Table 7 (given in fractions), we see that predicted increase in effort due to the wind and NZA closure and displacement scenarios is consistent with observed variability in effort at a fishing ground, and remains below the minimum observed variability for the different gears. This means that increasing fisheries effort at the scales predicted and shown in Table 7 are feasible. Only, under the Hard Brexit scenarios, the predicted increase in effort per cell exceeds the maximal observed variability in effort. This means that is unlikely that the predicted increases in effort could be realised.

\subsection{Impact on benthos}

At higher fishing intensity, the number of times the seafloor is trawled increases. Such an increase results in lower benthic biomass (Rijnsdorp et al. 2018). The overall loss in benthic biomass in fished areas can, however, be negated by the areas that are closed for fishing (e.g. windfarms and Natura 2000 sites). The overall impact of spatial closures on benthic biomass are calculated for the Dutch EEZ only and are given in Table 8. The impact on benthic biomass cannot be separated for each fleet segment as it relies on the sum of trawled seafloor. Therefore only the average biomass in a grid cell (scaled between 0 and 1 ) and total sum of all cells in the EEZ can be calculated. Results show that benthic biomass is largely unaffected in any of the scenarios. Average biomass shows at most $2 \%$ increase compared to the scenario with the highest impact (Decom NZA vessels + catch, $97.5^{\text {th }}$ percentile) or a $3 \%$ decrease (Decom Hard Brexit vessels, $2.5^{\text {th }}$ percentile, Table 8 ). The number of fishing grounds (i.e. grid cells) with a zero-fishing impact (thus associated with a biomass of 1 ) increase from the Status Quo to the Hard Brexit scenario as more areas are being closed. The benefit of a reduction in fishing grounds is however evened out by additional loss of biomass in those areas that remain open and receive a higher fishing effort.

\section{Table 8}

Relative Benthic State(RBS) of the seafloor in the Dutch EEZ under the different scenarios. 95\% interval for decommissioning scenarios are given between square brackets.

\begin{tabular}{|c|c|c|c|c|c|c|c|}
\hline & SQ & Wind & NZA & Hard Brexit & $\begin{array}{c}\text { Decom NZA } \\
\text { vessels }\end{array}$ & $\begin{array}{c}\text { Decom NZA } \\
\text { vessels + } \\
\text { catch }\end{array}$ & $\begin{array}{c}\text { Decom } \\
\text { Hard Brexit } \\
\text { vessels }\end{array}$ \\
\hline $\begin{array}{l}\text { Relative } \\
\text { average } \\
\text { biomass per } \\
\text { fishing area }\end{array}$ & 0.8834 & 0.8837 & 0.8811 & 0.8603 & $\begin{array}{c}0.8821 \\
{[0.8764-} \\
0.8892]\end{array}$ & $\begin{array}{c}0.8933 \\
{[0.8899-} \\
0.8990]\end{array}$ & $\begin{array}{c}0.8622 \\
{[0.8550-} \\
0.8699\end{array}$ \\
\hline
\end{tabular}

\subsection{Impact on $\mathrm{CO}_{2}$ emissions}

Results show that overall $\mathrm{CO}_{2}$ emissions are hardly affected under the Wind, NZA and Decommissioning NZA scenarios (Table 9). Although there is a larger investment in steaming under the Wind and NZA scenarios, this is countered by the reduction in fishing effort needed to maintain catch value in the fisheries operations. The investment under the NZA scenario is less than under the Wind scenario as fishing effort is less displaced to areas that would pass a windfarm. When comparing the NZA with the Decommissioning NZA scenario it is clear that, on average, vessels with a higher steaming investment get decommissioned and therefore $\mathrm{CO}_{2}$ emissions reduce. The same effect of decommissioning is clear in the comparison of the Hard Brexit and Decommissioning Hard Brexit scenarios. 
Under the Hard Brexit scenarios, fishers are forced to fish closer to the Dutch coastline, resulting in a reduction in steaming distance. Overall however, they require more effort to catch the same volume of fish as competition within the remaining areas increases and, as a consequence, catch rates drop.

When part of the fleet is decommissioned and the associated catch is no longer fished (i.e. the Decom NZA vessels + catch scenario), effort drops all together and this also automatically results in a substantial reduction in $\mathrm{CO}_{2}$ emissions.

\section{Table 9}

Relative change in \% in $\mathrm{CO}_{2}$ emission compared to the Status-Quo scenario. 95\% interval for decommissioning scenarios are given between square brackets.

\begin{tabular}{|c|c|c|c|c|c|c|}
\hline & Wind & NZA & $\begin{array}{l}\text { Hard } \\
\text { Brexit }\end{array}$ & Decom NZA vessels & $\begin{array}{c}\text { Decom NZA vessels + } \\
\text { catch }\end{array}$ & $\begin{array}{c}\text { Decom Hard Brexit } \\
\text { vessels }\end{array}$ \\
\hline $\begin{array}{l}\text { \% change in } \\
\text { CO2 emission } \\
\text { steaming }\end{array}$ & 8 & 4 & -4 & {$[-4-2]$} & $\begin{array}{c}-10 \\
{[-15--6]}\end{array}$ & {$[-12--5]$} \\
\hline $\begin{array}{l}\text { \% change in } \\
\text { CO2 emission } \\
\text { fishing }\end{array}$ & 0 & 1 & 4 & {$[-2-2]$} & {$\left[-17^{-15}-11\right]$} & $\begin{array}{c}4 \\
{[1-6]}\end{array}$ \\
\hline $\begin{array}{l}\text { \% change in } \\
\text { total } \mathrm{CO} 2 \\
\text { emission }\end{array}$ & 1 & 1 & 3 & $\begin{array}{c}0 \\
{[-2-2]}\end{array}$ & $\begin{array}{c}-14 \\
{[-16--11]}\end{array}$ & {$\left[0_{-}^{2}\right]$} \\
\hline
\end{tabular}

\subsection{Impact on unwanted bycatch}

Unwanted bycatch is directly related to the amount of effort in each grid cell. If effort in a cell goes up, the unwanted bycatch in that specific grid cell will go up as well. However, given that certain closed areas may overlap with hotspots of the predominant unwanted bycatch species, unwanted bycatches may overall go down. As the distribution of unwanted bycatch species differs for each species, the overall change in unwanted bycatch differs between species and scenarios.

\section{Table 10}

Relative change (\%) in unwanted bycatch for six species compared to the Status-Quo scenario, 95\% interval for scenario 4 and 5 are given between square brackets.

\begin{tabular}{|c|c|c|c|c|c|c|}
\hline & Wind & NZA & Hard & Decom NZA vessels & Decom NZA vessels + & Decom Hard Brexit \\
\hline & & & Brexit & & catch & vessels \\
\hline Dab & -1 & 1 & 12 & $1\left[-2{ }^{-4}\right]$ & $-13[-15--10]$ & $12[9-14]$ \\
\hline Plaice & 0 & 3 & 9 & $3[1-5]$ & $-12[-15--9]$ & $9[7 \ldots 11]$ \\
\hline Rays & 1 & -2 & -28 & $-2[-7-2]$ & $-22[-27--17]$ & $-28[-32--23]$ \\
\hline Sole & 1 & 4 & -2 & $3[1-6]$ & $-12[-17--8]$ & $-3[-5-0]$ \\
\hline Turbot & 1 & 4 & 17 & $4[2-7]$ & $-7[-10--4]$ & $17[14 \ldots 20]$ \\
\hline Whiting & 1 & 4 & 0 & $2[-3-6]$ & $-11\left[-16{ }_{-}-6\right]$ & $-2\left[-8 \_2\right]$ \\
\hline
\end{tabular}

With the addition of new windfarm areas, there is little change in the overall unwanted bycatch (Table 10, Wind scenario). The closed windfarm areas are generally too small to have a substantial effect on the bycatch of species. Under the NZA and also the Decommissioning NZA scenario, unwanted bycatch of the main target species goes up while unwanted bycatch of rays goes down. Under the Hard Brexit and Decommissioning Hard Brexit scenario, there are substantial changes in the unwanted bycatch of species. Ray unwanted bycatch drops the most (up to $28 \%$ ) while Turbot unwanted bycatch increases. Rays are known to mainly occur in hotspots closer to the UK coastline and it is therefore logical that under a closure of the UK EEZ, unwanted bycatch of rays by the Dutch fleet drops. Also bycatch of 
undersized Sole predominantly occurs on UK EEZ and therefore a drop in bycatch is to be expected. Turbot is caught mainly further north and most within the Dutch, German and Danish EEZ. These areas face less surface area closures under any of the scenarios and therefore effort is displaced to these regions. This subsequently leads to higher bycatches of Turbot. Overall, there is little difference in change in unwanted bycatch between a fleet composed of the current vessels or only the subset remaining after decommissioning, but the results show that unwanted bycatches may decrease by a couple of percent under certain decommissioning scenarios

\subsection{Qualitative summary of the results}

Table 11 shows a qualitative summary of the results under the different scenarios, in comparison to the Status Quo scenario. There results show that the benthic impact and $\mathrm{CO}_{2}$ emissions have similar directions throughout all scenarios. The scenario where catch from decommissioned vessels would no longer be fished by the remaining fleet (Decom vessels + catch) results in lower impact on all ecological indicators. Finally, the Wind scenario shows no significant difference to the Status Quo scenario.

\section{Table 11}

Qualitative summary of the effects on the ecological indicators of the different scenarios for scenarios without decommissioning $(2,36)$ and with decommissioning $(4,5,7)$, compared to Status Quo. Upward pointing arrows indicate an increase, horizontal pointing arrows indicate no change and downward pointing arrows indicate a decrease.

Benthic impact




\section{Discussion}

\subsection{Main results}

In this report, we predict the ecological impacts of reallocation of Dutch demersal fishing activities in six scenarios and compared to the Status Quo condition. These six scenarios include three scenarios without decommissioning; (2) Wind: expansion of OWFs, (3) NZA: expansion of OWFs and MPAs, and (6) Hard Brexit (on top of the combination of expansion of OWFs and MPAs) resulting in no access to UK waters; and three scenarios with a decommissioning scheme: (4) Decom NZA vessels: the combination of expansion of OWFs and MPAs and the opening of a decommissioning scheme for the MFL1-segment of the Dutch fleet while all catch of decommissioned vessels is fished in the remaining fleet, (5) Decom NZA vessels and catch: similar to (4) but with the catch of those vessels that are decommissioned no longer being available for the remaining fleet, and (7) Decom Hard Brexit: similar to (6) but with decommissioning of vessels (as in 4, see scenario description in Table 1).

We stress that the Hard Brexit scenario used in this study and its associated outcomes do not reflect the outcome of the actual Brexit agreement of 24 December 2020 (EU et al., 2020). When the study was commissioned, there was no indication what the eventual outcome of the Brexit negotiations would be. This is why we used the worst-case scenario.

Our results (Table 11) show that for the three ecological indicators studied here - relative benthic state, $\mathrm{CO}_{2}$ emissions and unwanted bycatch - continued construction of windfarms (scenario 2, Wind) and allocation of Natura 2000 areas (scenarios 3 NZA, and 4 Decom NZA vessels) have limited impact on these indicators. The ecological impacts of a Hard Brexit (scenario 6) will generally result in higher $\mathrm{CO}_{2}$ emissions and lower unwanted bycatch of rays but in higher bycatch of other species, and will have a negative effect on relative benthic biomass in the Dutch waters.

However, when the additional spatial closures are combined with a decommissioning scheme, we expect small to large positive effects on the ecology (Tables 8, 9 and 10). When catch from the decommissioning vessels is no longer fished by the remaining fleet (the extreme Decom NZA vessels + catch scenario 5), all ecological indicators decrease, indicating a positive impact on the ecology of the Dutch EEZ. In the other extreme, when all catch (value) from decommissioned vessels is caught by the remaining fleet (Decom NZA vessels, 4), the ecological impact remains the same or show a small positive effect compared to the respective scenario without decommissioning (Table 11).

The results demonstrate that the average condition of a fishing ground (relative benthic state) remains more or less stable under most of the scenarios. Due to the closure for the fishing fleet, the surface area where benthic species can return to unimpacted conditions increases. The ecological function of unimpacted benthic communities may be different as they will contain larger densities of long-lived species that will not survive the trawling intensities shown under the Status-Quo condition. However, at least for the scenarios where catch of decommissioned vessels is fished by the remaining fleet, this is traded off for a larger area where trawling intensities and benthic impact increases, resulting in reduction of medium to long-lived species in particular. As currently, there are no European reference points defining Good Environmental Status for benthic communities (Marine Strategy Framework Directive), we cannot assess implications of the various scenarios on the quality of the benthic communities. For the same reason, our study is not based on the assumption that the ecological indicators we used are currently in a bad/poor state.

The $\mathrm{CO}_{2}$ emission by the fishing fleet remain the same or decrease under all scenarios, except for Hard Brexit, compared to the Status-Quo condition. This is directly driven by a shift of the fleet segments to areas closer to the Dutch coastline, hereby reducing steaming distance. Under the Hard Brexit scenario, more $\mathrm{CO}_{2}$ is emitted driven by a decrease in fleet efficiency; in other words, the fleet 
fishes longer on fishing grounds where CPUEs drop faster due to increased exploitation competition compared to the Status-Quo situation. This is further discussed below.

Changes in unwanted bycatch are directly related to the result of displaced effort. Our results show clearly that spatial closures of southern North Sea areas have a positive impact on the unwanted bycatch of rays species, while Turbot is faced with higher unwanted bycatches. Overall, with the exception of the Wind scenario, all scenarios have a positive effect on unwanted bycatch of rays, the most vulnerable (from a life history perspective) species in our assessment. Rays are often long-lived, produce offspring in markedly lower numbers and are hence more prone to suffer from fishing pressure. Although bycatch is unwanted in any kind of fishery, Sole, Turbot, Whiting and Plaice are all associated with data-rich stock assessments and in the event of increases in bycatches of these species, appropriate TAC management can counter these impacts. Under the Wind scenario, the increases and decreases in bycatch of these species are small.

Furthermore, the simulations show that depending on the combinations of vessel decommissioning, ecological status could improve or degrade. As such, careful consideration of which vessels should be encouraged to decommission may be of interest for the management. This study, however, is not designed to provide further insight into these aspects.

\subsection{Critical assumptions}

The results are driven primarily by three critical assumptions:

1. Within a grid cell, CPUE at the start of a month is defined based on historical data and is not affected within a simulation due to displacement and effort changes. Catch per unit of effort decreases with fishing effort following Rijnsdorp et al. (2011), and CPUE is reset to its initial value at the beginning of each month.

2. There is no cap on effort in any grid cell.

3. Fishing effort is displaced only to areas previously visited by the fleet segments.

The use of these assumptions results in scenarios where the fleets can catch the same amount of fish using less effort and hence demonstrate an increase in efficiency. The fleet can use less effort overall if they relocate to areas where they fish on fishing grounds that are naturally associated with higher CPUEs. In this specific case, effort is displaced from low CPUE cells (located in areas that are planned to be closed due to windfarm or Natura2000 development) to high CPUE cells (outside of these areas planned to be closed). At the same time, the effect of a decrease in CPUE specific for each fishing ground (i.e. grid cell) is smaller than the effect of relocating effort from naturally lower to naturally higher CPUE grounds. The small decrease in effort is in line with the ecological concept of optimal foraging (Stephens, 1986). Optimal foraging means that a group of predators extensively exchange information to optimize the group's uptake and hence use as little effort as possible for the necessary intake. This kind of exchange is not representative for the fishing fleets. In addition, the fishery is assumed to optimize profits rather than value of the catch (as done in the model).

The first assumption, the decline in CPUE with increased effort, is modelled following the findings of Rijnsdorp et al. (2011). In this study we do not account for interference competition. With increases in effort, crowding at a fishing ground could result in an additional reduction of CPUE (Rijnsdorp et al. 2011). We expect this impact to be low given the low fishing effort within grid cells as estimated based on the 2015-2019 data. This effort is well below a threshold value of 80h of fishing per week, beyond which crowding becomes inevitable. If crowding would take place, total effort needed to maintain catches would have increased across all scenarios. Sensitivity analyses (not shown) indicate that even larger declines in CPUE will not result in differences in the interpretation of the study.

The results show that under nearly all scenarios evaluated, total effort needed to maintain catch value at the same level as in the Status-Quo scenario, stays the same or increases/decreases slightly. The exceptions are the Hard Brexit scenarios where one fleet segment needs to increase their effort by $13 \%$, another by $9 \%$ and two fleets by $7 \%$ (Table 6 ). Although the remaining open fishing grounds suffer from an increase in effort and as such a decline in CPUE, the fishers concentrate their effort in 
areas naturally associated with higher CPUEs, i.e., requiring lower effort to fish the same catch (following the second assumption, there is not cap on effort in grid cells). The efficiency improvements shown here (Table 6 ) represent a few percent in most scenarios. We consider it possible to improve the fisheries' efficiency with perfect knowledge of resource densities (as in the optimal foraging theory of Stephens, 1986). There are, however, factors limiting the increase of effort in those high CPUE grid cells (such as weather, personal preference, historical knowledge of fishing grounds, bycatch of unwanted species, etc.). Comparing the historical variability to the increase of effort per grid cell indicates that, with the exception of the Hard Brexit scenarios, the increases in effort simulated remain within the observed range, indicating that the slight decrease in total effort and efficiency gain are feasible. We again note that the Hard Brexit scenario used in this study and its associated outcomes do not reflect the outcomes of the final Brexit deal of 24 December 2020.

The third assumption is supported by findings of Hintzen et al. (2020) who found that fishing grounds of beam trawlers are extremely stable in space and time. Preliminary analyses on the spatial segregation of the fishing fleet indicate that fishers are very 'site faithful', likely to be driven by historic fishing activity and knowledge of the region. This, in combination with having to adhere to different (non-EU) regulations, may explain why the Dutch fishing fleet has no interest to fish further north into the Norwegian zone for the largest category Plaice, while scientific evidence from the International Bottom Trawl Survey (IBTS) clearly demonstrates the occurrence of high biomass of large sized Plaice in this area. Although it is unlikely that fishers will not displace effort to lesser visited fishing grounds or even unexplored areas, we expect that in the scenarios without Hard Brexit, the fishers will remain predominantly in the areas they are accustomed to. In the Hard Brexit scenarios, the level of effort predicted in historical fishing grounds largely exceed the observed variability and is therefore unlikely (Table 7). Noting that under decommissioning scenarios it is likely that the remaining fleet will also fish in the areas fished by the decommissioned vessels, results will become intermediate between NZA and Decommissioning NZA or Hard Brexit and Decommissioning Hard Brexit scenario results.

\subsection{Implications of the results}

The results from the scenarios as presented in this report should be seen relative to each other. This modelling study is an exploration into the direction of ecological responses to reallocation of fishing effort of the Dutch demersal fleet under different closure scenarios, and provides insight in the quantitative dimensions of possible ecological responses. It is important to note here that as part of the marine Strategy Framework Directive, no reference points have as yet been defined for any of the ecological indicators.

The expansion of areas closed for fishing, as is presented in this study by different scenarios, clearly indicates that substantial ecological improvements cannot be expected by the closure of the areas itself. Additional management actions are necessary for reduced of $\mathrm{CO}_{2}$ emissions, improved benthic community state and reduced unwanted bycatch. Specific selections of vessels to be decommissioned under the Decommissioning NZA scenario may contribute to ecological improvements. However, under all circumstances, a trade-off will remain between $\mathrm{CO}_{2}$ emissions and unwanted bycatch (while benthic impact is largely insensitive). Only when management decisions result in withholding (part of) the catch and quota of decommissioned vessels, ecological improvement can be expected on all indicators compared to the Status Quo condition. The scenario Decom vessels + catch simulates the scenario in which none of the catch of decommissioned vessels is fished by the remaining fleet. There could, however, be conditions in which part of the catch is fished by the remaining fleet, while still achieving ecological improvement.

Overall, a substantial increase in effort is necessary in the areas that remain open after expansion of wind farms and MPAs to fully exploit the current quotas (i.e. the effort that was previously allocated inside the closed areas is displaced to areas outside). In some areas, this is likely beyond what is locally sustainable (local depletion of stocks). When part of the fleet is decommissioned, increasing the effort implies that some fishers need to prolong their fishing trip, potentially beyond normal weekly or two-weekly trips. 


\subsection{Uncertainty of the simulations}

With regard to the economic data that form the basis of the simulation of the decommissioning scheme, it is important to note that the buyout values as used in this study are an indication for modelling purposes. They do not represent true buyout value, nor should they be used as a basis for a discussion on the height of the decommissioning scheme. The requirements for the final decommissioning scheme will be determined by the then applicable circumstances, which may lead to different assumptions and calculations. The Wadden Fund's remediation scheme for the brown shrimp fleet may serve as an example: at the time of calculating the buyout value, very different (market) conditions applied than at the time when the decommissioning scheme was drawn up. The result was that the number of applications for the buyout scheme was too small to make it a success. Differences in interpretation in the drivers for decommissioning could lead to different decommissioning probabilities and hence affect the results.

It is also important to take into account that in this study, fishers still fish in areas associated with high steaming costs or that are surrounded by closed areas. Making use of a full dynamic fleet behavioural model is required to evaluate whether these areas would still be frequented. Such a model is, however, currently not available. Predicting fleet behaviour is in our case extra complex for the Hard Brexit scenarios, as we do not know how closure of the UK EEZ will influence the fleet dynamics. We consider a very large displacement of effort to only known grounds unlikely, but a suitable alternative is lacking.

In our analyses, we did not include international data (data of other fleets). We were limited to the data of the demersal fleet under Dutch registration. This results in a more conservative result. Especially benthic impact is highest when an area is swept by a bottom trawler for the first and second time. The impact of the first time swept is high, while the $9^{\text {th }}$ or $10^{\text {th }}$ time barely has an extra impact on the benthic state. Leaving out international data leads more often to a first encounter compared to when international data including swept area, would have been included. On the other hand, more effort of international vessels would require displacement that could end up in lesser exploited grounds with potential high impact on the benthic communities and faster declines in CPUE.

The prediction of the distribution of all fleet segments is complex, as in practice fishing behaviour is related to many factors including abundance and distribution of target species, quota allocations (and possibilities for international quota swaps or quota leases amongst Dutch fishers), historic preferences for fishing locations (personal knowledge about fishing grounds) combined with other choices fishers make at sea. The case of the pulse fleet (active in the 2015-2019 period used for our analysis) is illustrative given that the use of pulse gear in the North Sea will be prohibited after July 2021. We expect most (former) pulse fishers to revert back tickler chains. With the transition from beam trawls with tickler chains to pulse fishing, a shift in distribution was visible, but that was most likely related to a shift in Sole density too (Vansteenbrugge et al., 2020). It is unclear how the reverse switch from pulse trawls to beam trawls with tickler chains will influence the distribution of tickler chain vessels. Furthermore, predictions of the distribution of some fleet segments under the Hard Brexit scenario are highly uncertain given the substantial displacement of effort that is needed to maintain catches at the Status Quo level.

Other important changes in the fleet concern the increase of flyshoot fishers in the North Sea and the English Channel. This fishery has a large footprint per hour of fishing due to its swept area (Rijnsdorp et al., 2020a). The number of active vessels, and hence ecological impact, has considerably increased in the past years. However, the number of flyshoot vessels is expected to remain stable as there is a limited number of licences available to fish in the English Channel and for a year-round profitable fishery, a flyshoot vessel is dependent on fishing both in the North Sea and the English Channel (WECR, economic data).

A final question relating to predicting fleet behaviour, is whether or not after decommissioning the remaining fishers will be able to catch the same value of fish as is caught by the current fleet. To exploit additional quota, the remaining fishers will need to spend additional time at sea. Even if fishers could reorganize their operations so that they can fish additional days, local depletion of fish stocks 
may occur. This could, because of a cost-benefits considerations, lead to quota not being fully exploited in the end. Our current model cannot account for local depletion scenarios. Ultimately, the full exploitation of the available quota within a year may simply be impossible if the fleet is too small. To show the direction of potential impacts on the ecological scenarios if this would be the case, we included the extreme scenario (scenario 5, Decom NZA vessels + catch).

Currently there is no model available that can account for (differences in) economic behaviour (including limitations in effort and economic constraints) of individual vessels. If socio-economic factors would be included, e.g. through an individual based fleet behavioural model accounting for, amongst other, ITQs ownership, different results in terms of displacement could be achieved. In view of the many marine spatial planning changes that will occur in the North Sea over the next years, the development of a full dynamic fleet behavioural model is urgently needed. 


\section{Quality Assurance}

Wageningen Marine Research utilises an ISO 9001:2015 certified quality management system. This certificate is valid until 15 December 2021. The organisation has been certified since 27 February 2001. The certification was issued by DNV GL. 


\section{References}

Batsleer, J., Marchal, P., Vaz, S., Vermard, V., Rijnsdorp, A.D. \& J.J. Poos (2018). Exploring habitat credits to manage the benthic impact in a mixed fishery. Mar. Ecol. Prog. Ser. 586: 167-179.

Brunel, T., Verkempynck, R., Van Broekhoven, W., \& J. Batsleer. 2019. Best Practices II. Spatial distribution of the discards of the Dutch beam trawler fleet. IJmuiden: Wageningen Marine Research, report C015/19.

Daw, T. M., Cinner, J. E., McClanahan, T. R., Brown, K., Stead, S. M., Graham, N. A., \& J. Maina. 2012. To fish or not to fish: indicators at multiple scales affecting artisanal fishers' readiness to exit a declining fishery. PLoS One, 7(2).

Eigaard, O. R., Bastardie, F., Breen, M., Dinesen, G. E., Hintzen, N. T., Laffargue, P., Mortensen, L. O., et al. 2016. Estimating seabed pressure from demersal trawls, seines, and dredges based on gear design and dimensions. ICES Journal of Marine Science, 73: i27-i43.

EU,EAEC, UK \& Northern Ireland. 2020. Trade and cooperation agreement between the European Union and the European Atomic Energy Community, of the one part, and the United Kingdom of Great Britain and Northern Ireland, of the other part. 24 December 2020.

https://ec.europa.eu/info/sites/info/files/draft_eu-uk_trade_and_cooperation_agreement.pdf

Hiddink, J. G., Jennings, S., Sciberras, M., Bolam, S. G., Cambiè, G., McConnaughey, R. A., Mazor, T., et al. 2019. Assessing bottom trawling impacts based on the longevity of benthic invertebrates. Journal of Applied Ecology, 56: 1075-1084.

Hiddink, J. G., Jennings, S., Sciberras, M., Szostek, C. L., Hughes, K. M., Ellis, N., Rijnsdorp, A. D., et al. 2017. Global analysis of depletion and recovery of seabed biota after bottom trawling disturbance. Proceedings of the National Academy of Sciences of the United States of America, 114: 8301-8306.

Hintzen, N. T., Bastardie, F., Beare, D., Piet, G. J., Ulrich, C., Deporte, N., \& J. Egekvist, J. et al. 2012. VMStools: Open-source software for the processing, analysis and visualisation of fisheries logbook and VMS data. Fisheries Research, 115-116: 31-43.

Hintzen, N. T., Piet, G. J. \& Brunel, T. 2010. Improved estimation of trawling tracks using cubic Hermite spline interpolation of position registration data. Fisheries Research, 101: 108-115.

Hoefnagel, E. W. J., Visser, L. E. \& de Vos, B. I. 2004. Drijfveren van vissers en duurzaam visserijbeheer; Een verkenning. LEI.

Klimaatwet. 2019.

Minister EZK. 2020. Kabinetsaanpak klimaatbeleid. Brief van de Minister van Economische Zaken en Klimaat aan de voorzitter van de Tweede Kamer der Staten-Generaal. Den Haag, 4 december 2020.

Minister LNV. 2020. Appreciatie van het advies van mevrouw Burger voor een duurzame kottervisserij. Brief van de Minister van Landbouw, Natuur en Voedselkwaliteit aan de voorzitter van de Tweede Kamer der Staten-Generaal. Den Haag, 19 juni 2020.

Mol, B.W. Zaalmink, N.A. Steins \& M.L. Kraan. 2019. Vissen bij wisselend tij; Een notitie over de (cumulatieve) sociaaleconomische effecten van ontwikkelingen die invloed hebben op de Nederlandse kottervisserij. Wageningen, Wageningen Economic Research, Nota 2019-063. 
OFL. 2020. Het Akkoord voor de Noordzee. 58 pp. Den Haag: Overlegorgaan voor de Fysieke Leefomgeving.

Pitcher, C. R., Ellis, N., Jennings, S., Hiddink, J. G., Mazor, T., Kaiser, M. J., Kangas, M. I., et al. 2017. Estimating the sustainability of towed fishing-gear impacts on seabed habitats: a simple quantitative risk assessment method applicable to data-limited fisheries. Methods in Ecology and Evolution, 8: 472-480.

Planbureau. 2020. Augustusraming 2020-2021. Retrieved from CPB: https://www.cpb.nl/augustusraming-2020-2021

Poos, J.J. and Rijnsdorp, A.D., 2007. An "experiment" on effort allocation of fishing vessels: the role of interference competition and area specialization. Canadian Journal of Fisheries and Aquatic Sciences 64 (2), 304-313

Poos, J. J., Turenhout, M. N., van Oostenbrugge, H. A. \& A.D. Rijnsdorp. 2013. Adaptive response of beam trawl fishers to rising fuel cost. ICES Journal of Marine Science, 70: 675-684.

Quirijns, F. J., Steins, N. A., Zaalmink, B. W., Mol, A., Kraan, M., Strietman, W. J., van Asseldonk, M. A. P. M., Molenaar, P., van Oostenbrugge, J. A. E. \& W. H. M. Baltussen. 2019. Duurzame Noordzee kottervisserij in ontwikkeling: Ervaringen, lessen en bouwstenen. (Wageningen Marine Research rapport; No. C085/19). Wageningen Marine Research. https://doi.org/10.18174/499389

Rijksoverheid. 2018. Routekaart Wind Op Zee 2030. Retrieved May 10th from https://www.noordzeeloket.nl/functies-gebruik/windenergie-zee/in-ontwikkeling-op/

Rijnsdorp, A.D., Poos, J.J., Quirijns, F.J., Grant, J., 2011. Spatial dimension and exploitation dynamics of local fishing grounds by fishers targeting several flatfish species. Canadian Journal of Fisheries and Aquatic Sciences 68 (6): 1064-1076

Rijnsdorp, A. D., Bolam, S. G., Garcia, C., Hiddink, J. G., Hintzen, N. T., van Denderen, P. D. \& T. van Kooten. 2018. Estimating sensitivity of seabed habitats to disturbance by bottom trawling based on the longevity of benthic fauna. Ecological Applications, 28: 1302-1312.

Rijnsdorp, A. D., Hiddink, J. G., Denderen, P. D. Van, Hintzen, N. T., Eigaard, O. R., Valanko, S., Bastardie, F., et al. 2020a. Different bottom trawl fisheries have a differential impact on the status of the North Sea seafloor habitats. ICES Journal of Marine Science.

Rijnsdorp, A. D., Depestele, J., Eigaard, O. R., Hintzen, N. T., Ivanovic, A., Molenaar, P., O'Neill, F., et al. 2020b. Mitigating ecosystem impacts of bottom trawl fisheries for North Sea sole (Solea solea) by replacing mechanical by electrical stimulation. bioRxiv.

Salas, S., \& Gaertner, D. 2004. The behavioural dynamics of fishers: management implications. Fish and fisheries, 5(2), 153-167.

Salz, P., Hoefnagel, E. W. J., Bavinck, M., Hoex, L., Bokhorst, J., Blok, E., \& J. Quaedvlieg. 2008. Maatschappelijke gevolgen van de achteruitgang in de visserij. Den Haag: Landbouweconomisch Instituut.

Soma, K. 2003. How to involve stakeholders in fisheries management-a country case study in Trinidad and Tobago. Marine Policy, 27(1), 47-58.

Stephens, D. and Krebs, J.R., 1986. Foraging theory. Princeton University Press (1)

Taal, V. O. (2010). Methodiek economische waardebepaling aalvisrechten, LEI nota VR10-003. Den Haag: Landbouweconomisch Instituut. 
Taal, Van Oostenbrugge \& Smit, 2010b. Methodiek economische waardebepaling aalvisrechten. LEI nota VR10-003. Den Haag: Landbouweconomisch Instituut.

Turenhout, Baltussen, \& Taal. 2016a. Waardeberekening van vergunningen van garnalenvissers in de Waddenzee. Notitie Wageningen Economic Research.

Turenhout, M. N. J., Zaalmink, B. W., Strietman, W. J., \& Hamon, K. G. 2016b. Pulse trawling in the Netherlands: economic and spatial impact study (No. 2016-104). Wageningen: Wageningen Economic Research.

Wilson, R. J., Speirs, D. C., Sabatino, A. \& M.R. Heath. 2018. A synthetic map of the north-west European Shelf sedimentary environment for applications in marine science. Earth System Science Data, 10: 109-130.

Vansteenbrugge, L., Sys, K., Nimmegeers, S., Vandecasteele, L., Vanelslander, B., Vandemaele, S., Vanderperren, E., Polet, H. \& Torreele, E. 2020. Pulsvisserij Vlaamse Kust, deel 1. ILVO Mededeling 258. Oostende: Instituut voor Landbouw-, Visserij- en Voedingsonderzoek.

Van Hoof, L., Steins, N.A., Smith, S. \& Kraan, M. 2020. Change as a permanent condition: A history of transition processes in Dutch North Sea fisheries. Marine Policy, online 6 October 2020. https://doi.org/10.1016/j.marpol.2020.104245

Zaalmink, W., Hoekstra, G., Mol, A., \& Strietman, J. (2018). Sociaal-economische gevolgen van een totaal verbod van pulsvisserij voor de Nederlandse visserijsector (No. 2018-044). Wageningen Economic Research.

Zuur, A. F., Ieno, E. N., Walker, N. J., Saveliev, A. A. \& G.M. Smith. 2009. Mixed effects models and extensions in ecology with R. 1-574 pp. 


\section{Justification}

Report C029.21

Project Number: 4318100252

The scientific quality of this report has been peer reviewed by a colleague scientist and a member of the Management Team of Wageningen Marine Research

Approved: $\quad$ dr. Ingrid Tulp

Senioy researcher, Wageningen Marine Research

Signature:

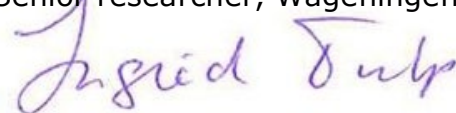

Date:

March 26th 2021

Approved:

dr. ir. Sander van den Burg

Signature:

Approved: $\quad$ dr. ir. Tammo Bult

Director Wageningen Marine Research

Signature:

Date:

March 31th 2021 


\section{Annex A: Selection criteria for vessels eligible for decommissioning}

\section{Eligible vessels}

The envisaged decommissioning scheme targets vessels of the Dutch cutter fleet that belong to segment MFL 1, with a length of minimum 15 meter and a tonnage less than 1.200 BT. These vessels must be actively registered (personal communication ministry of Agriculture, Nature and Food Quality, 2020). Vessels targeting brown shrimp (Crangon crangon) in this segment will not be eligible for the scheme (OFL, 2020).

For this exercise, the most recent composition of the Dutch demersal fleet is used. Vessels targeting brown shrimp more than $90 \%$ of the trips are left out of defining the probability and buyout value since they are not eligible for this specific decommissioning scheme. The composition of the fleet in 2019 is used, adapted to the most recent inside information on vessels that are either sold abroad or sunk since 2019. These vessels are removed from the list of vessels.

Based on the selection criteria presented above, the total number_of vessels eligible for the decommissioning scheme is 165 .

\section{Defining influencing factors}

A primary selection of possible factors that influence the decision to voluntarily opt for the decommissioning scheme was made based on previous (international) literature (i.e. Salas \& Gaertner, 2004; Mol et al., 2019; Quirijns et al., 2019; Daw et al., 2012). Secondly, the relevance of each factor for the Dutch cutter fleet was discussed among experts and the list was adapted. The final selection of factors and the source is shown in Table A. The relevance and assumed effect of each factor is elaborated on further below under Expected future profitability.

\section{Table A}

Selection of factors influencing the decision on decommissioning: literature and data source

\begin{tabular}{|c|c|c|}
\hline Influencing factors & Assumption & Literature Source \\
\hline Age of engine ship & $\begin{array}{l}\text { The older the engine, the higher the } \\
\text { more likely to decommission. }\end{array}$ & Mol et a., 2019 \\
\hline Saleability of vessel & $\begin{array}{l}\text { The lower the saleability of the } \\
\text { vessel, the more likely to } \\
\text { decommission. }\end{array}$ & Curtis et al., 2016 \\
\hline Multi-functionality of ship & $\begin{array}{l}\text { The fewer available gears to target } \\
\text { other species on different fishing } \\
\text { grounds, the more likely to } \\
\text { decommission. }\end{array}$ & Mol et al., 2019 \\
\hline $\begin{array}{l}\text { Dependency on areas that will be/might be } \\
\text { closed in the future }\end{array}$ & $\begin{array}{l}\text { The higher the dependency on } \\
\text { areas to be closed in the future } \\
\text { (windfarms, nature areas), the } \\
\text { more likely to decommission. } \\
\text { Fishing at other site is costlier than } \\
\text { current situation. }\end{array}$ & Mol et al., 2019 \\
\hline Business succession & $\begin{array}{l}\text { No one to take over the business in } \\
\text { the future, means more likely to } \\
\text { decommission. }\end{array}$ & $\begin{array}{l}\text { Salz, et al., } 2008 \text { (LEI); Daw et al., } \\
\text { 2012; etc. etc. } \\
\text { Mol et al., } 2019\end{array}$ \\
\hline
\end{tabular}




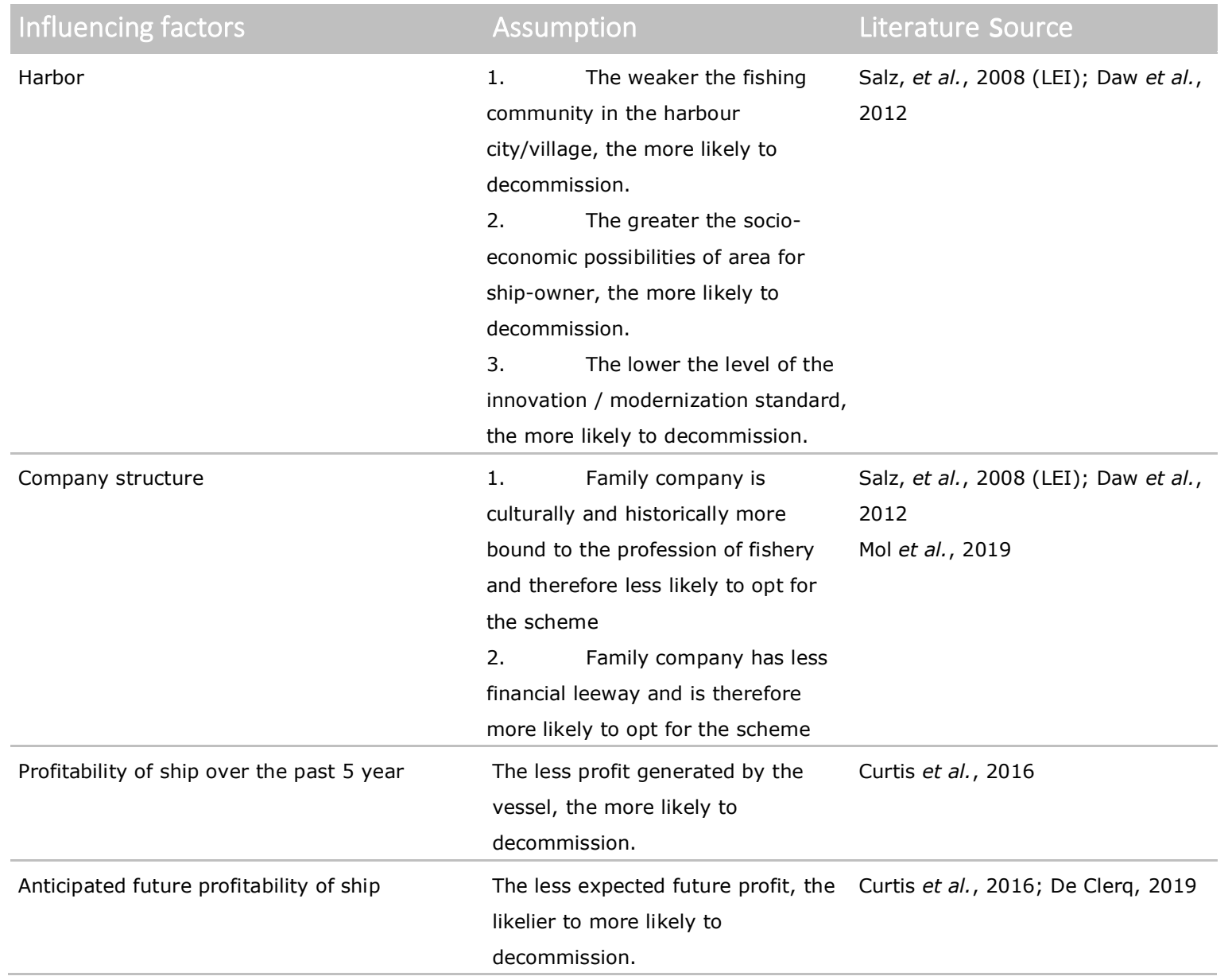

The following points have been considered in the process of drafting the list of factors:

- Assessing and quantifying the likelihood of decommissioning for an individual vessel has not been done before in studies and our methodology is relatively new. Therefore, the literature study focused on the question which socio-economic indicators influence the decision of a fisher to stop fishing or drivers for decommissioning in other sectors (e.g. Dutch pig farming: De Clerq, 2019). Since a great number of Dutch demersal North Sea fishers only own one vessel, opting for the decommissioning scheme equals the end of their occupation in fisheries. For companies with multiple vessels, giving up one vessel can mean a reduction in effort and sometimes the need to search for other sources of income (expert opinion).

- A further requirement for selecting the factors is whether the factor can be quantified on shiplevel. Data needs to be available, either from the economic database from Wageningen Economic Research, from EU fleet registry or from satellite data, logbook and auction data.

- Selection of experts involved in drafting the list: Researchers of Wageningen Economic Research (WECR) and Wageningen Marine Research (WMR), including staff who gather economic and biological data in the field.

- Factors that were considered but not included in the list were:

- External factors like; gas and oil price or the status of the fish stocks (Mol et al., 2019); these have an influence on the future of fishery. However, they are hard to predict and cannot be measured on ship level.

- The economic position of the company, specifically: whether the company is in dept (De Clerq, 2019; Curtis et al., 2016). Decommissioning might mean an elevation from dept for the company owner. However, when the decommissioning amount is insufficient to cover the dept, it might still not be possible to exit the market (De Clerq, 2019). Data on the economic position of specific companies is not freely available. The profit over the past 5 years can be seen as a proxy for this factor.

- Identification of the fisher with his/her profession (Salz et al., 2008; Daw et al., 2012). This social factor is mentioned on international studies on small-scale fishery and might be less relevant for the Dutch cutter fleet. More research is necessary to assess this. This 
indicator is left out of this study since there is no data available to quantify it on ship level.

- The driving factors do not need to be independent of each other. The decision to decommission is a very complex decision with a variety of interlinking factors feeding into it. This list is a simplification in which the effect of each factor on the decision to decommission is considered independently. The aim is not to do a statistical analysis.

\section{Assignment of weights attached to indicator and category}

A workshop was organized to discuss the factors in depth, to define categories in order to quantify each vessel per factor and finally to assign weights. The weights were assigned-using the methodology presented by Soma (2003). Soma (2003) elaborates on a method called the analytical hierarchy process (AHP) which can be used in stakeholder meetings to gather information from the field for improved sustainable fisheries management. In this exercise, the assessment of the importance of management objectives-was adapted to the factors and belonging categories.

In the AHP method, the objectives, criteria or options of a case are organized into a "decision tree". Figure a shows the adaptation of the decision tree to the objective of the workshop with an example of how weights could be assigned.

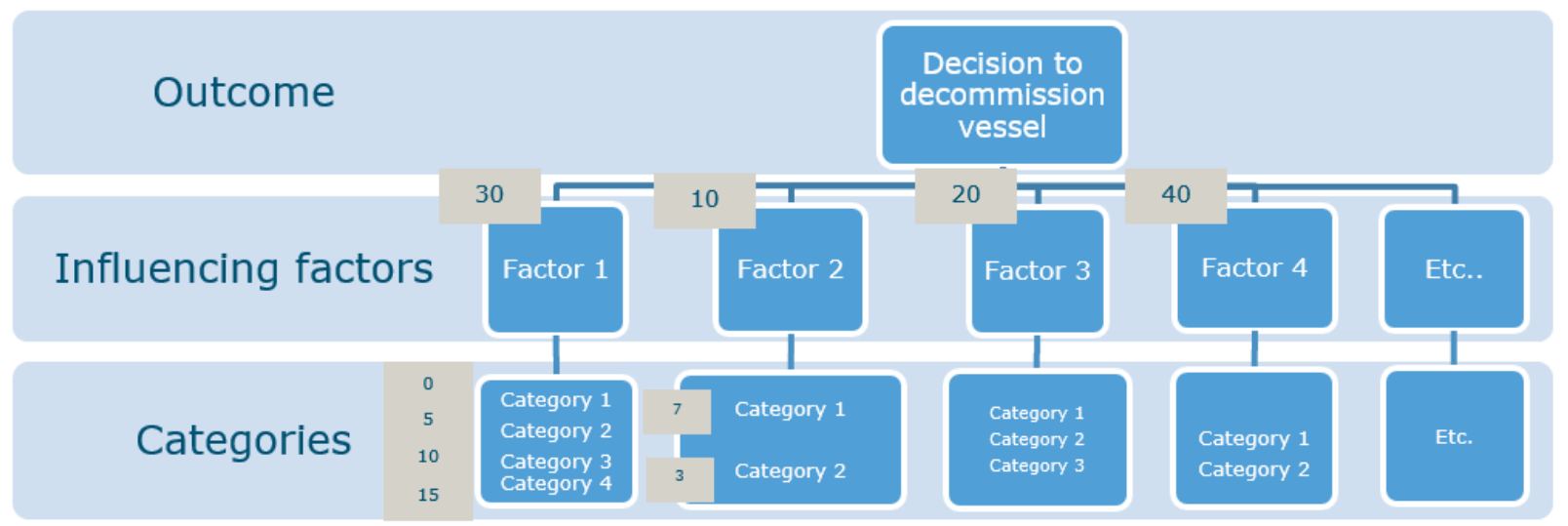

Figure a Theoretical illustration of the decision-tree used in the workshop and example of assigning weights

To generate the scores for the various indicators and categories, a comparison of the elements using a nine-point weighting scale is used in the AHP (Soma, 2003). Each stakeholder (or in our case expert) can then individually score the elements based on their importance. For simplicity reasons and because our target group was comparatively small, we used a 100-point system in the workshop that participants could divide over the influencing indicators. The higher the score assigned to an indicator, the greater the expected influence of the indicator on the outcome (decommissioning of the vessel). Another 100 points were given to divide over categories belonging to each indicator. Here, higher scores represent a higher probability for decommissioning of the vessel.

After individually assigning scoring points to both indicators and categories, the results of each expert were compared and arguments for their choices were presented. Participants were then allowed to adjust their answers if deemed necessary.

\section{Quantification and effect of indicators}

In this subsection the relationship between the indicator and the outcome, the arguments for the categories and the method of quantification are discussed per indicator.

\section{Expected future profitability}

The future profitability of a vessel is closely connected with the uncertainty experienced by the fisher when assessing the future. There are many future uncertainties which likely have an impact on the future profitability in the fishery sector and which effects are difficult to forecast.

The indicator measures the future developments in the economic performance relative to past profit; this can be stable, uncertain or down. The choice has been made to base the direction on three 
measurable factors that experts have assessed as important future drivers for the economic performance or adding uncertainty:

- $\quad$ how much the vessel fished in the areas to be closed according to the North Sea Agreement,

- $\quad$ how much the vessel has been fishing in British waters. This adds uncertainty since the implications of Brexit for Dutch fishing vessels fishing in UK waters are not yet clear,

- $\quad$ whether a vessel used to fish with a pulse license. Fishing with pulse gears generates a high profit (Turenhout et al., 2016b). Since pulse will be banned from 2021 onwards, this will likely result in generally lower revenue for these vessels when combined with more than $10 \%$ dependency on to be closed areas stated in the North Sea Agreement.

Figure $B$ and $C$ show the categorization of the indicator based on the three factors described above. For each vessel their position in the matrix is assessed. This is done based on data retrieved from the Vessel Monitoring System (VMS), logbook details and the fish prices. For a more detailed description of the methodology, see above and Hintzen et al (2012).

\begin{tabular}{|c|c|c|c|c|c|}
\hline \multirow[t]{2}{*}{ With pulse: } & & \multicolumn{4}{|c|}{ British territorial waters: $\%$ of total revenue } \\
\hline & & $0 \%$ & $0-10 \%$ & $10-35 \%$ & $>35 \%$ \\
\hline \multirow{4}{*}{$\begin{array}{c}\text { North Sea Agreement } \\
\text { closed areas: } \% \text { of total } \\
\text { revenue }\end{array}$} & $0 \%$ & uncertain & uncertain & uncertain & uncertain \\
\hline & $0-10 \%$ & uncertain & uncertain & uncertain & uncertain \\
\hline & $10-35 \%$ & down & down & down & down \\
\hline & $>35 \%$ & down & down & down & down \\
\hline
\end{tabular}

Figure B Categorisation of vessels fishing with pulse: expected future profitability

\begin{tabular}{|c|c|c|c|c|c|}
\hline \multirow[t]{2}{*}{ Without pulse: } & & \multicolumn{4}{|c|}{ British territorial waters: $\%$ of total revenue } \\
\hline & & $0 \%$ & $0-10 \%$ & $10-35 \%$ & $>35 \%$ \\
\hline \multirow{4}{*}{$\begin{array}{c}\text { North Sea Agreement } \\
\text { closed areas: } \% \text { of total } \\
\text { revenue }\end{array}$} & $0 \%$ & stable & stable & uncertain & uncertain \\
\hline & $0-10 \%$ & stable & stable & uncertain & uncertain \\
\hline & $10-35 \%$ & uncertain & uncertain & uncertain & uncertain \\
\hline & $>35 \%$ & down & down & down & down \\
\hline
\end{tabular}

Figure C Categorisation of vessels fishing without pulse: expected future profitability

\section{Business succession of owner}

The absence of business succession means a higher likelihood for the owner to decide to decommission their vessel(s). This indicator is rather straightforward; if there is no one to take over the business it will not continue. This is especially important in the fishing industry since fishing enterprises are usually small and family owned (Mol et al., 2019). The indicators are categorized as:

- yes, there is someone who wants to take over the business or the owner is relatively young (under 40) and succession is not yet relevant,

- uncertain, and

- no.

Data is collected through interviews with accountants and or expert judgement

3. Historical dependency on future closed areas

We expect that vessels retrieving a bigger part of their income from fishing activity in areas that will be closed in the North Sea Agreement are likelier to opt for decommission. These fishers will lose part of their fishing grounds and will need to reallocate their activities to areas which might be less efficient and/or more crowded (Mol et al., 2019). As fishers can be emotionally attached to their fishing grounds, the need to reallocate might also lower their morale (Quirijns, et al., 2019).

For this indicator, a combination of log data kept by all fishers on the activity and catch is used, together with VMS data on the location of the vessels. Combining these two datasets allows us to locate effort and catch of each vessel to the areas that will be closed in the future (Hintzen et al., 2012). An average for the years 2015-2019 was used to account for fluctuations in prices and catch due to extreme external influences. The categories were defined as a percentage of the total value of landings per vessel: 
- $\quad 0 \%$ of total value of landings,

- $1-9 \%$ of total value of landings,

- $\quad 10-34 \%$ of total value of landings,

- $\quad 35 \%$ and more of total value of landings.

The areas that will be closed are defined in the North Sea Agreement and the roadmap giving the locations of future windfarms in 2030 as well as current and future OFWs and N2000 areas outside the Dutch EEZ are shown in figure 1. The areas in the north of the Dutch EEZ that are currently being investigated as potential OWFs locations are not considered because of future uncertainty.

\section{Age of the engine of the vessel}

The age of the engine is a contributing factor in the decision to opt for decommissioning. An older engine is related to higher fuel consumption and higher maintenance costs (Quirijns, et al., 2019). Moreover, for a vessel with a new engine fishers (recently) had to make a significant investment for the future, making it unlikely the owner plans on applying for decommissioning (Quirijns, et al., 2019).

The categories for this indicator are:

- $\quad$ zero to ten years, indicating a brand-new engine,

- ten to twenty years, indicating a relatively new engine,

- $\quad$ twenty to 35 years, indicating an older engine, and

- older than 35 years, indicating an exceptionally old engine.

These cut off points are based on the current structure of the fleet regarding engine age. Of the total number of vessels eligible for the decommissioning scheme, 32 vessels have an engine less than ten years, 66 vessels have an engine between 10 and 20 years, 64 vessels between 20 and 35 years and 3 vessels have an engine with an age of more than 35 years. The data is retrieved from the fleet registry.

\section{Past profitability}

It is expected that when a vessel made significant profit over the past five years, the probability is lower it will be decommissioned. This indicator is calculated based on economic data from the "Bedrijveninformatienet" (BIN, managed by Wageningen Economic Research). For vessels within the panel dataset, the average profit over the years 2015-2019 has been taken. The year 2019 is an approximation based on the average of the past 4 years since data was not yet available. The past profit of vessels not represented in the panel is calculated based on the daily fishing effort as retrieved from logbook data and the average net profit of vessels using the same fishing gear and settlings.

The indicator is categorized in:

- loss (<0 euros per year),

- profit (0-405,348 euros per year),

- $\quad$ high profit (>405,348 euros per year).

The cut-off point $€ 405,348$ is chosen since $25 \%$ of the vessels generate a yearly profit above this point.

\section{Saleability of vessel}

The more difficult it is to sell a vessel, the higher the probability that a fisher opts to decommission his/her vessel. There are 3 categories:

- good probability to sell,

- $\quad$ medium probability to sell,

- low probability to sell.

The saleability of a vessel is determined by the type of vessel, the age of the vessel (hull and engine), the physical state of the vessel and the licenses connected to the vessel. 
In the dataset this is quantified for each vessel based on expert knowledge of the vessel and interviews with accountants and vessel brokers.

\section{Multifunctionality of vessel}

Based on Quirijns et al. (2019), we make the assumption that a vessel that only has the possibility to fish with one gear will have a higher probability to be decommissioned than vessels that can switch to other gears and are thus multifunctional. This is related to the fact that multifunctional vessels will likely have more opportunities and less-fewer costs to divert to other areas and target other species when their current fishing grounds will be closed.

The multifunctionality of the vessel is measured in number of gears possibly used on the vessel and is categorized as one gear, two gears or three or more gears. Currently, the majority of the vessels have the possibility to fish with more than three gears. Around $20 \%$ out of the total vessels have one available gear.

In assigning the weight for this indicator, external factors that likely affect the connection of multifunctionality with accepting the decommissioning scheme are considered. For example, the possibility to target other fish species depends on the available quota at that moment (Quirijns et al., 2019) or the market prices for this fish species. Other factors considered are the areas possible to use the gear combined with the existing fishing activity in that area or the exact costs related to changing gears for the vessel. If the extra gear is pulse, it is not advantageous at all since the exemption on the pulse ban will end in 2021.

\section{Company structure}

The structure of the company is categorized in:

- family-owned company with 1 vessel,

- $\quad$ family-owned company with 2-5 vessels, and

- $\quad$ large company (or "rederij") with more than 5 vessels.

Like home port, the influence of this indicator can work in both directions: in a family company there is been found to be more loyalty to their business and profession (Daw et al., 2012) and therefore a lower probability for decommissioning. However, family companies have less financial leeway and therefore have a higher probability for decommissioning when revenue is in danger. For a company with multiple vessels the opposite is in general true. The contradicting effects result in a small effect of the indicator over-all as judged by the experts in the workshop.

The data comes from database "fishing enterprise EU". Per vessel the owner is listed. Secondly, the number of vessels registered under the same owner name are counted and listed for each owner. This number is then linked to each vessel.

\section{Home port}

The effect of the home port of the vessel and the fisher on the likelihood of decommissioning is a complex one drawing on the social structures of the home port (Salz et al., 2008). Based on existing literature on social fishing communities and expert discussions, multiple factors are relevant for this exercise:

- If a fisher community is very tight, fishers identify themselves more with their occupations and social pressure is likely to be high. Therefore, fishers will not easily quit their occupation (Daw et al., 2012) or decommission their vessels.

- If the area has a lot of socio-economic possibilities for vessel-owners, it is easier to find another job and to opt for decommissioning.

- $\quad$ In certain areas the level of innovation and modernization of the fleet is very high. Fishers in these areas are less likely to opt for decommissioning.

We identified three regions which differ in the probability of decommissioning of individual vessels:

- West (all parts in provinces of Zeeland, South and North Holland and the isle of Texel),

- $\quad$ North (ports of Harlingen and Eemshaven), and

- Urk. 
The data is retrieved from the VesselIDs of the vessels. For example, UK909 is registered at Urk, while IJM808 is registered in IJmuiden.

\section{Table B}

Result of workshop: indicators, associated categories and assigned weights relative to assessed importance. Ordered from most important to least important factor.

\begin{tabular}{|c|c|c|c|c|}
\hline Influencing indicators & $\begin{array}{l}\text { Assigned } \\
\text { scores* (total = } \\
100 \text { points) }\end{array}$ & $\begin{array}{l}\text { Categories } \\
\text { (measured on } \\
\text { vessel-level) }\end{array}$ & $\begin{array}{l}\text { Assigned scores to } \\
\text { categories within } \\
\text { indicators** (total } \\
=100 \text { points per } \\
\text { indicator) }\end{array}$ & Data source \\
\hline $\begin{array}{l}\text { Expected future } \\
\text { profitability of } \\
\text { vessel } \\
\text { Based on: pulse, } \\
\text { fishing in closed areas } \\
\text { and Brexit }\end{array}$ & 23.6 & $\begin{array}{l}\text { Stable } \\
\text { Uncertain } \\
\text { Down }\end{array}$ & $\begin{array}{l}3 \\
27 \\
70\end{array}$ & $\begin{array}{l}\text { Economic data sources } \\
\text { WEcR (i.a. "Bedrijven } \\
\text { Informatienet"), fleet } \\
\text { registry and VMS } \\
\text { (satellite monitoring) } \\
\text { and log data. }\end{array}$ \\
\hline $\begin{array}{l}\text { Business } \\
\text { succession present }\end{array}$ & 21.4 & $\begin{array}{l}\text { Yes } \\
\text { No } \\
\text { Uncertain }\end{array}$ & $\begin{array}{l}8 \\
64 \\
28\end{array}$ & $\begin{array}{l}\text { Interviews with fishers } \\
\text { and accountants }\end{array}$ \\
\hline $\begin{array}{l}\text { Historical } \\
\text { dependency value in } \\
\text { areas that will } \\
\text { be/might be closed in } \\
\text { the future (North Sea } \\
\text { Agreement) }\end{array}$ & 16 & $\begin{array}{l}0 \% \text { of total catch } \\
1-9 \% \text { of total } \\
\text { catch } \\
10-34 \% \text { of total } \\
\text { catch } \\
35 \% \text { and more of } \\
\text { total catch }\end{array}$ & $\begin{array}{l}2 \\
11 \\
28 \\
59\end{array}$ & $\begin{array}{l}\text { VMS + logbook + fish } \\
\text { auction data }\end{array}$ \\
\hline $\begin{array}{l}\text { Age of vessel } \\
\text { engine }\end{array}$ & 10.7 & $\begin{array}{l}\text { Less than } 10 \text { years } \\
\text { Between } 10 \text { and } \\
19 \text { years } \\
\text { Between } 20 \text { and } \\
34 \text { years } \\
35 \text { and more years }\end{array}$ & $\begin{array}{l}3 \\
16 \\
42 \\
40\end{array}$ & Fleet registry (WEcR) \\
\hline $\begin{array}{l}\text { Profitability of } \\
\text { vessel over the } \\
\text { past } 5 \text { year }\end{array}$ & 10 & $\begin{array}{l}\text { Loss } \\
\text { Profit } \\
\text { High profit }\end{array}$ & $\begin{array}{l}59 \\
30 \\
11\end{array}$ & $\begin{array}{l}\text { Economic data sources } \\
\text { WEcR (i.a. "Bedrijven } \\
\text { Informatienet"), fleet } \\
\text { registry and VMS and } \\
\text { logbook data. }\end{array}$ \\
\hline $\begin{array}{l}\text { Saleability of } \\
\text { vessel } \\
\text { Based on: vessel } \\
\text { type, age engine and } \\
\text { hull, physical state } \\
\text { and connected } \\
\text { licenses }\end{array}$ & 7.9 & $\begin{array}{l}\text { Good } \\
\text { Middle } \\
\text { Bad }\end{array}$ & $\begin{array}{l}4 \\
28 \\
68\end{array}$ & $\begin{array}{l}\text { Interviews and expert } \\
\text { knowledge }\end{array}$ \\
\hline $\begin{array}{l}\text { Multi-functionality } \\
\text { of vessel }\end{array}$ & 6 & $\begin{array}{l}1 \text { gear } \\
2 \text { gears } \\
3 \text { or more gears }\end{array}$ & $\begin{array}{l}56 \\
28 \\
16\end{array}$ & $\begin{array}{l}\text { Prepared for } \\
\text { "Kottervisie" (WEcR) }\end{array}$ \\
\hline
\end{tabular}


measured by $n$. of

gears

\begin{tabular}{|c|c|c|c|c|}
\hline Company structure & 2.9 & $\begin{array}{l}\text { Family owned } \\
\text { business ( } 1 \\
\text { vessel) } \\
\text { Family owned } \\
\text { business with } \\
\text { multiple vessels } \\
\text { Company with } \\
\text { more than } 5 \\
\text { vessels }\end{array}$ & $\begin{array}{l}26 \\
42 \\
32\end{array}$ & $\begin{array}{l}\text { Database "fishing } \\
\text { enterprise EU" }\end{array}$ \\
\hline Home port & 1.1 & $\begin{array}{l}\text { North } \\
\text { South } \\
\text { Urk }\end{array}$ & $\begin{array}{l}35 \\
55 \\
10\end{array}$ & Fleet registry (WEcR) \\
\hline
\end{tabular}

*The higher the scoring point for the indicator, the greater the effect on the probability of decommissioning

**The higher the scoring point for a category, the greater the likelihood that a vessel will decommission.

\section{Calculating the final probability of the specific vessel to decommission}

The results from the scoring exercise are used to decide on the unique probability of decommissioning for each vessel. The probability of decommissioning of the category the vessel falls under for that specific indicator is multiplied by the weight of the indicator itself. For example, Vessel $x$ has a stable expected future profitability. In table 2 it becomes clear that the score for the indicator future profitability is $\mathbf{2 3 . 6}$ and for the category stable is 3 . The contribution of the stable future profitability of Vessel $x$ to the total probability of decommissioning the vessel $=0.236 * 0.03(0,007$ or $0.7 \%$ increase in probability on decommissioning). Vessel $Y$, who expects its profitability to decrease will have a different calculation here: $0.236 * 0.7(0,17$ or a $17 \%$ increase in probability on decommissioning).

The outcome for each of these factors is summed for each vessel to come to the total probability of decommissioning. 


\section{Annex B: Defining buyout value}

This Annex B provides more detailed information on the calculations for the buyout value for decommissioning as used for the purposes of our ecological assessment, described in Chapter 2.2.1.

The data is retrieved from the Bedrijveninformatienet, managed by Wageningen Economic Research. The Bedrijveninformatienet contains economic data on vessel-level collected on a yearly basis from a representative sample of the Dutch cutter fleet. The following adjustments to the dataset have been made to prepare the dataset for the calculation:

- Until 2018, frequent logbooks errors were found in relation to registration of beam trawl and pulse trawls. For the latter new codes were introduced (PUL and PUK), but former beam trawl skippers who converted to pulse fishing often kept using the traditional TBB code (beam trawls with ticklers). Therefore, data managed by Wageningen Economic Research on the use of pulse gear by the Dutch flatfish fleet was applied to check whether vessels fished with beam trawl or pulse. Based on this expert judgement, these were categorized accordingly.

- $\quad$ For vessels that changed owner during the period 2015-2019, data from the first full year of ownership onwards is taken into account. For vessels bought in 2019 , there is no full year of data to base the calculation on. In these cases, the buyout value equals the purchase value of the ship (expert indication).

- Vessels in the hp-classes 3 (301-800) and 4 (801-1500) which are not represented in large numbers in these classes and have similar characteristics as vessels belonging to another hp class, have been regarded as these comparable vessels. This concerns for example large beam trawlers with reduced engine power.

- A few vessels occur multiple times in the dataset since a change in length or engine power requires a new registration. The average (weighted by the time period of the occurrence) of the values that occur multiple times but belong to the same vessel ID is used for these vessels.

The buyout value is calculated per vessel and linked to the probability of decommissioning. This is then used in the simulation. In Figure $D$ the distribution of the buyout value of the vessels is shown. The number of vessels is 165 . The buyout values are between $€ 89,647$ and $€ 8,000,000$ with an average of around $€ 2.19$ million. 


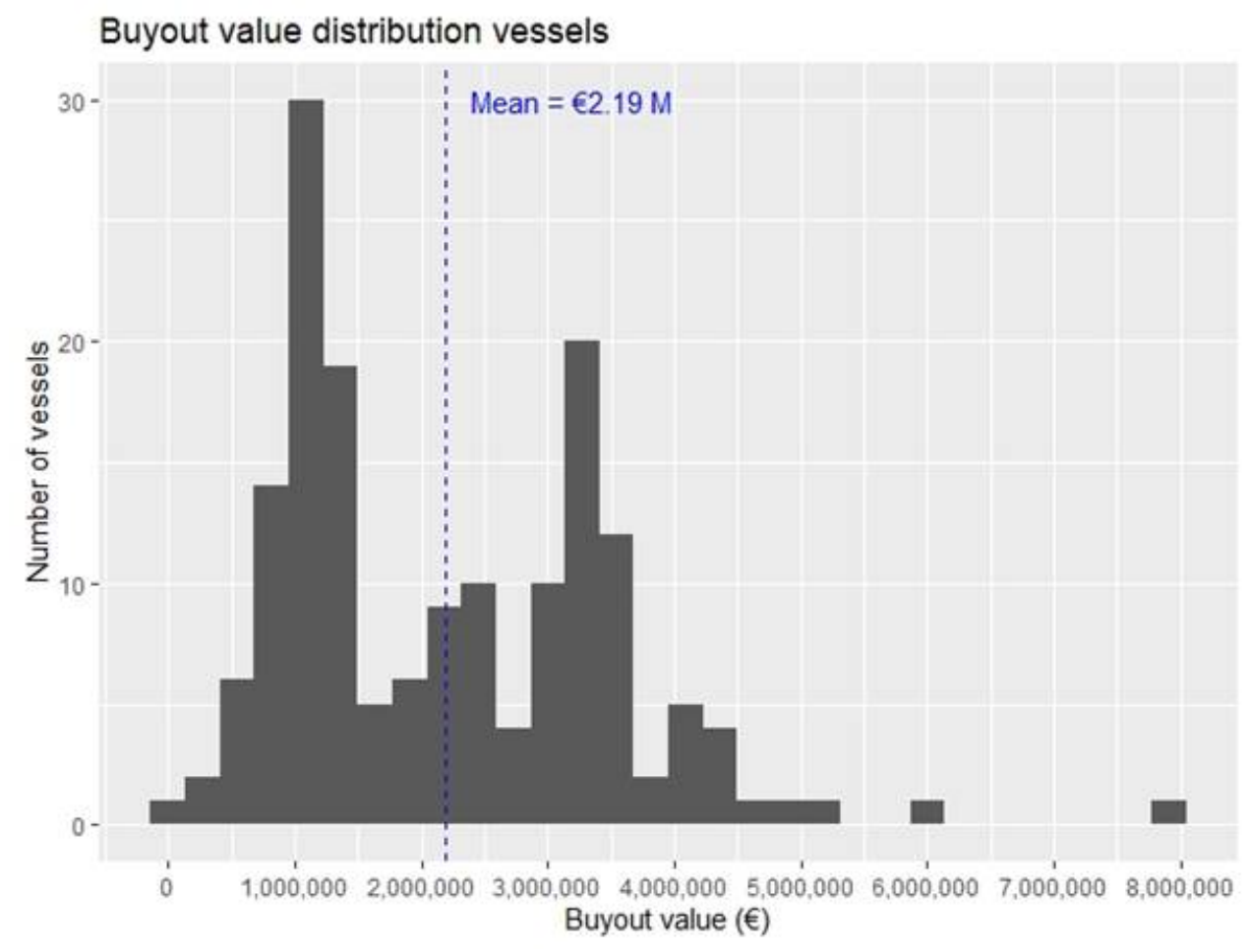

Figure D: Buyout value distribution vessels 
Wageningen Marine Research

$\mathrm{T}+31(0) 317480900$

E: marine-research@wur.nl

www.wur.eu/marine-research

Visitors' address

- Ankerpark 271781 AG Den Helder

- Korringaweg 7, 4401 NT Yerseke

- Haringkade 1, 1976 CP IJmuiden
With knowledge, independent scientific research and advice, Wageningen Marine Research substantially contributes to more sustainable and more careful management, use and protection of natural riches in marine, coastal and freshwater areas.

Wageningen Marine Research is part of Wageningen University \& Research. Wageningen University \& Research is the collaboration between Wageningen University and the Wageningen Research Foundation and its mission is: 'To explore the potential for improving the quality of life' 